\title{
Last Man Standing: Kansas's Failure to Recognize the Common Interest Doctrine
}

\author{
Nell Neary*
}

\section{INTRODUCTION}

Corporation B is currently on the verge of going under. Corporation A is considering acquiring Corporation $\mathrm{B}$, but before Corporation $\mathrm{A}$ agrees, it wants to know if Corporation $\mathrm{B}$ has any ongoing legal issues. Corporation $\mathrm{B}$ is currently engaged in litigation unrelated to the acquisition. Can Corporation B share litigation-related material with Corporation A? The outcome depends largely on whether the jurisdiction recognizes the common interest doctrine. In Kansas, such a communication would put Corporation $\mathrm{B}$ in a precarious situation. If Corporation $\mathrm{B}$ shares litigation-related materials with Corporation A, it likely waives its attorney-client privilege, and thus the litigation materials would become discoverable by the opposing party. However, if Corporation B does not share this information with Corporation A, it will likely lose the deal. The common interest doctrine's jurisdictional inconsistency makes this hypothetical a realistic possibility.

Generally, a client waives attorney-client privilege if they communicate previously privileged information to a third party. ${ }^{1}$ However, approximately ninety percent of jurisdictions recognize an exception to this rule known as the common interest doctrine. ${ }^{2}$ The common interest doctrine allows parties

* J.D. Candidate, 2018, University of Kansas School of Law; B.A., 2013, University of Kansas. I would like to thank Professor Suzanne Valdez for her valuable feedback and guidance during this process, as well as Mary Kate McWhirter and the members of the Kansas Law Review for their hard work and thoughtful review of this Comment.

1. E.g., People v. Harris, 442 N.E.2d 1205, 1208 (N.Y. 1982).

2. Over forty states have found that attorney-client privilege is not waived when confidential communications are shared among co-parties retaining separate counsel. Amended Brief \& CrossAppeal of Appellee-Cross Appellant British American Tobacco (Investments) Ltd., Smith v. Philip Morris Cos., 335 P.3d 644 (Kan. Ct. App. 2014) (No. 12-108491-A), 2013 WL 4038830, at *20-23 [hereinafter Amended Brief \& Cross-Appeal] (citing B.E. Meyers \& Co. v. United States, 41 Fed. Cl. 729, 732 (Fed. Cl. 1998) (finding that the common interest doctrine is "well recognized in all circuits that have considered it")); Ala. R. Evid. 502(b)(3); AlaSKa R. EviD. 503(b)(3); Ariz. Indep. Redistricting Comm'n v. Fields, 75 P.3d 1088, 1099-100 (Ariz. Ct. App. 2003) (quoting RESTATEMENT (THIRD) OF LAW GOVERNING LAWYERS § 76(1) (AM. LAW INST. 2000)); ARK. R. EVID. 502(b)(3); CAL. EvID. CODE $\S 952$ (West 2009) (comment to 1965 amendment); Gordon v. Boyles, 9 P.3d 1106, 1124 (Colo. 2000); McPhee Elec. Ltd., LLC v. Konover Constr. Corp., No. CV075009694, 2009 WL 455866, at*1 (Conn. Super. Ct. Jan. 29, 2009); DEL. R. EVID. 502(b)(3); 
sharing a common interest in a legal matter to share privileged information without waiving attorney-client privilege. ${ }^{3}$ Kansas is one of the last jurisdictions that still does not recognize the common interest doctrine in some form, ${ }^{4}$ every federal circuit has recognized the doctrine, as well as an overwhelming majority of state jurisdictions. ${ }^{5}$

The common interest doctrine generally requires (1) that attorney-client privilege serves as the basis of the claim, (2) the parties share a common interest, (3) the communication is made in furtherance of this interest, and

Volpe v. Conroy, Simberg \& Ganon, P.A., 720 So. 2d 537, 539 (Fla. Dist. Ct. App. 1998); Spence v. Hamm, 487 S.E.2d 9, 11 (Ga. Ct. App. 1997) (finding the common interest, referred to as the joint representation exception, did not apply); HAW. R. EVID. 503(b)(3); IDAHO R. EvID. 502(b)(3); Waste Mgmt., Inc. v. Int'1 Surplus Lines Ins. Co., 579 N.E.2d 322, 328-29 (Ill. 1991); Corll v. Edward D. Jones \& Co., 646 N.E.2d 721, 725 (Ind. Ct. App. 1995); Brandon v. W. Bend Mut. Ins. Co., 681 N.W.2d 633, 639-40 (Iowa 2004) (applying a “joint-client” privilege); KY. R. EVID. 503(b)(3); LA. CodE Evid. ANN. art. 506(B)(3) (2006); ME. R. EvID. 502(b)(3); Gallagher v. Office of the Attorney Gen., 787 A.2d 777, 784-85 (Md. Ct. Spec. App. 2001); Am. Auto. Ins. Co. v. J.P. Noonan Transp., No. 97-0325, 2000 Mass. Super. LEXIS 548, *18-25 (Mass. Super. Ct. Nov. 8, 2000); D’Alessandro Contracting Grp., LLC v. Wright, 862 N.W.2d 466, $473-75$ (Mich. Ct. App. 2014); Schmitt v. Emery, 2 N.W.2d 413, 416-17 (Minn. 1942), overruled by Leer v. Chi., Milwaukee, St. Paul \& Pac. Ry. Co., 308 N.W.2d 305 (Minn. 1981); Miss. R. EvID. 502(b)(3); Lipton Realty, Inc. v. St. Louis Hous. Auth., 705 S.W.2d 565, 570-71 (Mo. Ct. App. 1986); In re Rules of Prof'l Conduct \& Insurer Imposed Billing Rules \& Procedures, 2000 MT 110, ๆๆ 56-73, 299 Mont. 321, 2 P.3d 806; NEB. Rev. Stat. AnN. § 27-503(2)(c) (West 2009); Nev. Rev. Stat. AnN. § 49.095(3) (West 2004); N.H. R. Evid. 502(b)(3); LaPorta v. Gloucester Cty. Bd. of Chosen Freeholders, 774 A.2d 545, 54950 (N.J. Super. Ct. App. Div. 2001); N.M. R. EvID. 11-503(B)(3); Parisi v. Leppard, 660 N.Y.S.2d 307, 309-11 (N.Y. Sup. Ct. 1997); Nationwide Mut. Fire Ins. Co. v. Bourlon, 617 S.E.2d 40, 46-47 (N.C. Ct. App. 2005), aff'd, 625 S.E.2d 779 (N.C. 2006); N.D. R. EvID. 502(b)(3); OKLA. STAT. ANN. tit. 12, § 2502(B)(3) (West 2009 \& Supp. 2014); OR. ReV. STAT. ANN. § 40.225(2)(c) (West Supp. 2014); Young v. Presbyterian Homes Inc., 50 Pa. D. \& C.4th 190, 195-201 (Pa. Ct. Com. Pl. 2001) (providing table of authorities addressing common interest doctrine); Tobaccoville USA, Inc. v. McMaster, 692 S.E.2d 526, 531 (S.C. 2010) (limiting the doctrine to narrow factual situation); S.D. CoDIFIED LAWS § 19-19-502(b)(3) (Westlaw through 2016 Reg. Sess.); State v. von Bulow, 475 A.2d 995, 1008 (R.I. 1984); Vance v. State, 230 S.W.2d 987, 990-91 (Tenn. 1950) (citing Chahoon v. Commonwealth, 62 Va. (21 Gratt.) 822, 836-42 (Va. 1871)); TEX. R. EvID. 503(b)(1)(C); UTAH R. Evid. 504(b)(2)(A)-(B); VT. R. EviD. 502(b)(3); Hicks v. Commonwealth, 439 S.E.2d 414, 416-17 (Va. Ct. App. 1994) (citing Chahoon, 62 Va. (21 Gratt.) at 836-42); State v. Emmanuel, 259 P.2d 845, 854-55 (Wash. 1953) (citing Hartness v. Brown, 59 P. 491, 494-95 (Wash. 1899)); WIS. STAT. ANN. § 905.03(2) (West Supp. 2013)); see also Hanover Ins. v. Rapo \& Jepson Ins. Servs., Inc., 870 N.E.2d 1105, 1112 (Mass. 2007).

3. Ambac Assurance Corp. v. Countrywide Home Loans, Inc., 57 N.E.3d 30, 35 (N.Y. 2016) (quoting Teleglobe Commc'ns Corp. v. BCE, Inc. (In re Teleglobe Commc'ns Corp.), 493 F.3d 345, 364 (3d Cir. 2007)). The common interest doctrine has been referred to by various terms such as the "common interest arrangement," "common legal interest doctrine," "joint litigant privilege," "pooled information privilege," "allied lawyer doctrine" and "allied litigant privilege." Id. at 35 n.1. However, the name is less important than what determines the bounds of the doctrine. Id. (quoting N. River Ins. Co. v. Columbia Cas. Co., No. 90 Civ. 2518, 1995 WL 5792, at *2 (S.D.N.Y. Jan. 5, 1995)). For the purpose of this Comment, the term "common interest doctrine" is used.

4. At this time, the only jurisdictions not to recognize even a limited version of the common interest doctrine are Kansas, Ohio, West Virginia and Wyoming.

5. See Amended Brief \& Cross-Appeal, supra note 2, at *22. 
(4) the parties may not have otherwise waived the privilege. $^{6}$ The application of the common interest doctrine varies greatly and depends on both the circumstances and the jurisdiction. ${ }^{7}$ The doctrine's jurisdictional inconsistency makes it difficult, if not impossible, for attorneys to accurately predict what actions will waive attorney-client privilege and subject sensitive materials to discovery in a subsequent litigation. ${ }^{8}$ Parties seeking to reap the benefits of the common interest doctrine need to clear two general hurdles: first, the jurisdiction must recognize the doctrine; and second, the parties must have a sufficient "common interest" as defined by that state. ${ }^{9}$

Courts particularly struggle to define when parties share a "common interest." The most common approaches can be grouped into three stances: (1) courts do not recognize the common interest doctrine at all; (2) they recognize the common interest doctrine, but pending or anticipated litigation is required; or, most broadly, (3) they recognize the common interest doctrine as long as the parties share a common legal interest. ${ }^{10}$ The requirement, or lack thereof, of pending or anticipated litigation usually dictates whether the common interest doctrine can be applied in a transactional setting. ${ }^{11}$

Courts requiring pending or anticipated litigation reason that parties cooperating outside of litigation are less likely to have a common legal interest and are more likely serving their own commercial interests. ${ }^{12}$ In contrast, a number of courts have extended the common interest doctrine to situations outside of litigation. ${ }^{13}$ There are a number of legal situations in which parties cooperate outside of the litigation context: "applying for patents;" "conducting due diligence," in mergers, acquisitions, or other commercial transactions; "ensuring that mutually beneficial advertising is not misleading;" and ensuring compliance with the law in order to avoid "liability [or litigation] in the first place." ${ }^{14}$ Of these situations, the common

6. See Restatement (ThiRD) OF THE LAW Governing LAWYers $§ 76$, cmts. a-g (AM. LAW INST. 2000).

7. See discussion infra Section II.E.

8. See discussion infra Sections II.B \& D.2.

9. See discussion infra Section II.E.

10. See discussion infra Section II.E.

11. See discussion infra Section II.D.2.

12. See, e.g., Oak Indus. v Zenith Indus., No. 86 C 4302, 1988 WL 79614, at *4 (N.D. Ill. July 27, 1988); Ambac Assurance Corp. v. Countrywide Home Loans, Inc., 57 N.E.3d 30, 36-40 (N.Y. 2016).

13. See infra Section II.D.2.

14. Jared S. Sunshine, Seeking Common Sense for the Common Law of Common Interest in the D.C. Circuit, 65 Cath. U. L. Rev. 833, 844 (2016). 
interest doctrine has been most widely discussed in patent law and substantial business transactions, such as mergers and acquisitions. ${ }^{15}$ Both of these situations involve parties that are arguably adverse, as they generally sit on opposite sides of a negotiating table, but still have a common interest in the patent, or successful completion of the deal. ${ }^{16}$ Courts applying the common interest doctrine to such situations reason that they should not create a "procedural doctrine that restricts communication[s] between buyers and sellers, [and] erects barriers to business deals.",

This Comment argues that Kansas should recognize the common interest doctrine in a form that protects parties both within and outside the scope of anticipated or pending litigation. This form allows parties to predict whether information will be disclosed and furthers the rationale behind attorney-client privilege. Moreover, failure to recognize the common interest doctrine has both economic and ethical consequences for both Kansas attorneys and the Kansas judicial system.

Part II of this Comment provides the background of the common interest doctrine, including its roots in attorney-client privilege, its evolution from the joint defense doctrine, and an overview of the modern doctrine across jurisdictions, as well as Kansas. Part III argues that Kansas should recognize the common interest doctrine "to encourage the free flow of information and to enhance effective legal advice."18 Additionally, it argues that Kansas should recognize and define a fairly broad version of the common interest doctrine, in order to provide clarity and certainty to Kansas attorneys and best align itself with other persuasive jurisdictions.

\section{BACKGROUND}

The common interest doctrine is rooted in the attorney-client privilege doctrine and developed as an extension to the joint defense doctrine. ${ }^{19}$ Today, jurisdictions have recognized the common interest doctrine in a variety of forms, ranging from broadly-worded statutes to cases restricting the doctrine to narrow factual scenarios. ${ }^{20}$ Jurisdictions vary most on two

15. See, e.g., Robert A. Matthews, JR., 7 Annotated Patent Digest $§ 42: 35$, Westlaw (updated Mar. 2017) (collecting applications of the common interest doctrine in patent law); Anne King, Comment, The Common Interest Doctrine and Disclosures During Negotiations for Substantial Transactions, 74 U. CHI. L. REV. 1411, 1427-31 (2007).

16. King, supra note 15 , at 1426-32.

17. Hewlett-Packard Co. v. Bausch \& Lomb Inc., 115 F.R.D. 308, 311 (N.D. Cal. 1987).

18. Katharine Traylor Schaffzin, An Uncertain Privilege: Why the Common Interest Doctrine Does Not Work and How Uniformity Can Fix It, 15 B.U. PUB. INT. L.J. 49, 65 (2005).

19. See infra Sections II.C-D.

20. E.g., DEL. R. EVID. 502(b)(3); Tobaccoville USA, Inc. v. McMaster, 692 S.E.2d 526, 531 
issues: (1) defining a "common interest" and (2) whether litigation should be a requirement for parties to have a sufficiently common interest. ${ }^{21}$

\section{A. Attorney-Client Privilege}

The common interest doctrine is rooted in attorney-client privilege. Accordingly, the common interest doctrine has been characterized as both "an extension of the attorney-client privilege and ... as an exception to the traditional waiver of the attorney-client privilege." ${ }^{, 2}$ Attorney-client privilege applies to communications meeting the following elements: "(1) a communication (2) made between privileged persons (3) in confidence (4) for the purpose of obtaining or providing legal assistance for the client." 23 The client, the attorney(s), and any of their agents who help facilitate the attorney-client communications or legal representation are considered "privileged persons." 24 Only the client can waive the privilege. ${ }^{25}$ Because legal advice is often sought for the sole purpose of avoiding litigation or ensuring compliance with the law, the contemplation of litigation is not a prerequisite for protection under attorney-client privilege. ${ }^{26}$

Attorney-client privilege is considered the oldest common-law privilege and is an exception to the maxim that the public has the right to "every man's evidence." 27 It serves to encourage frank communication between attorneys and clients and in doing so, promotes the broader public interest "in the observance of law and administration of justice." 28 However, courts have reasoned that this also limits the truth-seeking process, so the privilege is generally construed narrowly. ${ }^{29}$ "[T] he mere fact that an attorney [is] involved . . . does not automatically" invoke the privilege; rather the "communication ... must relate to legal advice or strategy." 30 These same

(S.C. 2010).

21. See discussion infra Section II.D.

22. Schaffzin, supra note 18 , at 54-55.

23. RESTATEMENT (THIRD) OF THE LAW GOVERNING LAWYERS $§ 68$ (AM. LAW INST. 2000).

24. Id. at $\S 70$.

25. See, e.g., Haines v. Liggett Grp. Inc., 975 F.2d 81, 90 (3d Cir. 1992) (citing 4 MCCORMICK ON EvidENCE $\S 92$ (John W. Strong ed., 1992)); Chahoon v. Commonwealth, 62 Va. (21 Gratt.) 822, 841 (Va. 1871).

26. E.g., Spectrum Sys. Int'l Corp. v. Chem. Bank, 581 N.E.2d 1055, 1061 (N.Y. 1991).

27. In re Qwest Commc'ns Int'l Inc., 450 F.3d 1179, 1185, 1195 (10th Cir. 2006) (first quoting Trammel v. United States, 445 U.S. 40, 50 (1980); then quoting United States v. Nixon, 418 U.S. $683,710(1974))$.

28. Upjohn Co. v. United States, 449 U.S. 383, 389 (1981).

29. See Nixon, 418 U.S. at 709-10.

30. In re Grand Jury Proceedings, 616 F.3d 1172, 1182 (10th Cir. 2010) (first quoting Motley v. Marathon Oil Co., 71 F.3d 1547, 1550-51 (10th Cir. 1995); then quoting United States v. Johnston, 146 F.3d 785, 794 (10th Cir. 1998)). 
ideals extend to the common interest doctrine and as such, the justifications and critiques of attorney-client privilege carry over to the common interest doctrine. $^{31}$

Corporations, like individual clients, can claim attorney-client privilege. ${ }^{32}$ Attorney-client privilege allows corporations to structure their behavior in a way that complies with the law through advice from corporate counsel. ${ }^{33}$ In Upjohn Co. v. United States, the Supreme Court articulated the rationale for corporations' use of attorney-client privilege, reasoning that a narrow interpretation of the privilege "not only makes it difficult for corporate attorneys to formulate sound advice when their client is faced with a specific legal problem but also threatens to limit the valuable efforts of corporate counsel to ensure their client's compliance with the law." ${ }^{34}$ The Court went on to distinguish individuals' and corporations' use of the law: "[C]orporations, unlike most individuals, 'constantly go to lawyers to find out how to obey the law,' particularly since compliance with the law in this area is hardly an instinctive matter." 35 The Upjohn decision reinforced the universally accepted idea that corporate communications deserve protection under attorney-client privilege, just as individuals are entitled to. ${ }^{36}$ However, the applicability of this idea under the common interest doctrine is largely uncertain, as jurisdictions have inconsistently applied the doctrine to situations involving corporate attorney-client privilege. ${ }^{37}$

Because the common interest doctrine is rooted in attorney-client privilege, it cannot apply unless the underlying communication would have been protected prior to its disclosure. ${ }^{38}$ Therefore, it is critical that the underlying communication is protected by attorney-client privilege and has not been otherwise waived, or the common interest doctrine is not applicable.

31. See Ambac Assurance Corp. v. Countrywide Home Loans, Inc., 57 N.E.3d 30, 44-48 (N.Y. 2016) (Rivera, J., dissenting).

32. Upjohn Co., 449 U.S. at 389-90.

33. Id. at 392 .

34. Id.; see also King, supra note 15, at 1421 (citing Upjohn Co., 449 U.S. at 392).

35. Upjohn Co., 449 U.S. at 392 (citations omitted) (quoting Bryson P. Burnham, The Attorney-Client Privilege in the Corporate Arena, 24 Bus. LAw. 901, 913 (1969)).

36. Id. at 389-90.

37. See discussion infra Section II.D.2.a.

38. Schaffzin, supra note 18 , at 55-56. 


\section{B. Waiver of Attorney-Client Privilege}

Generally, the disclosure of an otherwise privileged communication to a third party constitutes a waiver of attorney-client privilege. ${ }^{39}$ Similarly, communications made in the presence of third parties are not privileged. ${ }^{40}$ These acts of disclosure signal that the communication was not intended to be kept confidential or secret. ${ }^{41}$ Waiver can be express, or implied through actions. $^{42}$ Implied waiver is especially high risk because waiving attorneyclient privilege on one communication - for example, a patent opinion-will usually waive all communications related to that matter, such as emails, memoranda, and other communications related to the patent. ${ }^{43}$ Moreover, even a discussion of the privileged communications' general subject matter may constitute an implied waiver. ${ }^{44}$ Other courts, concerned by the potentially grave consequences of implied waiver, only find an implied waiver if it jeopardizes fairness - such as when communications are partially disclosed and fairness requires disclosure of the entire communication "to provide a complete context." 45

The common interest doctrine works as an exception to implied waiver for communications made to a third party sharing a common legal interest. ${ }^{46}$ The purpose of the doctrine, similar to that of attorney-client privilege, is "to encourage the free flow of information and [] enhance the quality of legal advice. ${ }^{, 47}$ By protecting parties with a common legal interest from waiving attorney-client privilege, the common interest doctrine allows attorneys and

39. Thomas M. Geisler, Jr., Proof of Waiver of Attorney-Client Privilege, 32 Am. JuR. Proof OF FACTS 3d 189, § 8 (Feb. 2017 update, Westlaw).

40. E.g., Ambac Assurance Corp. v. Countrywide Home Loans, Inc., 57 N.E.3d 30, 35 (N.Y. 2016) (quoting People v. Harris, 442 N.E.2d 1205, 1208 (1982)).

41. Teleglobe Commc'ns Corp. v. BCE Inc. (In re Teleglobe Commc'ns Corp.), 493 F.3d 345, 361 (3d Cir. 2007) (citing PAUl R. Rice, ATtORNEY-Client PRIVILEgE IN THE UNITED STATES $\S$ 9:28 (2d ed. 1999)).

42. King, supra note 15, at 1421.

43. See Smith v. Alyeska Pipeline Serv. Co., 538 F. Supp. 977, 980-82 (D. Del. 1982).

44. See Am. Optical Corp. v. Medtronic, Inc., 56 F.R.D. 426, 431-33 (D. Mass. 1972) (holding a lawyer's disclosure of certain opinions during licensing negotiations did not waive privilege).

45. King, supra note 15, at 1421-23; see also Hewlett-Packard v. Bausch \& Lomb, Inc., 115 F.R.D. 308, 311 (N.D. Cal. 1987) (citing Richard L. Marcus, The Perils of Privilege: Waiver and the Litigator, 84 Mich. L. REV. 1605, 1627-28 (1986)).

46. Schaffzin, supra note 18 , at 50, 55 .

47. Id. at 51; see, e.g., In re Grand Jury Subpoenas, 89-3 \& 89-4, John Doe 89-129, 902 F.2d 244, 249 (4th Cir. 1990) (quoting United States v. Schwimmer, 892 F.2d 237, 243 (2d Cir. 1989)); Visual Scene, Inc. v. Pilkington Bros., 508 So. 2d 437, 440-41 (Fla. Dist. Ct. App. 1987). 
their clients to make more precise predictions about the risk of waiver and how to avoid it. ${ }^{48}$

\section{The Joint Defense Doctrine}

The common interest doctrine evolved from the joint defense doctrineone of the first expansions on the scope of attorney-client privilege. ${ }^{49}$ The joint defense doctrine was the first exception to the general rule that attorney-client privilege is waived upon disclosure of privileged communications to a third party. ${ }^{50}$ It applies when a client shares privileged information with co-defendants for the purpose of forming a common defense strategy. ${ }^{51}$ The doctrine was originally only applied to criminal codefendants ${ }^{52}$ but has since been expanded to include civil co-defendants. ${ }^{53}$

The 1871 case, Chahoon v. Commonwealth, ${ }^{54}$ is recognized as the first case to apply the joint defense doctrine. ${ }^{55}$ In Chahoon, Virginia's highest court permitted criminal defense attorneys to coordinate their clients' strategies and still retain attorney-client privilege for their communications. ${ }^{56}$ The court reasoned:

[W] hether they [employed the same counsel, or employed different counsel as they did], the effect is the same, as to their right of communication to each and all of the counsel, and as to the privilege of such communication. They had the same defence [sic] to make, the act of one ... being the act of all, and the counsel of each was in effect the counsel of all, though, for purposes of convenience, he was employed and paid by his respective client. They had a right, all the accused and their counsel, to consult together about the case and the defence, [sic] and it follows as a necessary consequence, that all the information, derived by any of the counsel from such consultation, is privileged, and the privilege belongs to each and all of the clients, and cannot be released without the consent of all of them.

\footnotetext{
48. See Schaffzin, supra note 18 , at 54 .

49. Ambac Assurance Corp. v. Countrywide Home Loans, Inc., 57 N.E.3d 30, 35-37 (N.Y. 2016).

50. See id.

51. Id. at 35 (quoting Teleglobe Commc'ns Corp. v. BCE Inc. (In re Teleglobe Commc'ns Corp.), 493 F.3d 345, 364 (3d Cir. 2007)).

52. Id. at 35 .

53. See Schmitt v. Emery, 2 N.W.2d 413, 415-417 (Minn. 1942), overruled by Leer v. Chi., Milwaukee, St. Paul \& Pac. Ry. Co., 308 N.W.2d 305, 309 (Minn. 1981).

54. 62 Va. (21 Gratt.) $822,830-43$ (1871).

55. Schaffzin, supra note 18 , at 58 .

56. $62 \mathrm{Va}$. (21 Gratt.) at 830-43.

57. Id. at $841-42$.
} 
Almost seventy-five years passed before the Minnesota Supreme Court expanded the joint defense privilege from strictly criminal co-defendants to include civil co-defendants in Schmitt v. Emery. ${ }^{58}$ Counsels for several codefendants exchanged a privileged document to prepare for objections to the document's admission into evidence. ${ }^{59}$ The court held that this communication between counsel was privileged because the communication was made "in confidence, for the limited and restricted purpose to assist in asserting their common claims." ${ }^{\text {60 }}$ Schmitt marked the first steps toward today's common interest doctrine.

\section{The Modern Common Interest Doctrine: Two Major Issues}

As courts began to expand the joint defense doctrine from strictly criminal co-defendants, the common interest doctrine emerged. ${ }^{61}$ Nevertheless, jurisdictions did not apply it uniformly, creating confusion and inconsistency about how and when the doctrine applies. ${ }^{62}$ Generally, courts that recognize the doctrine require the invoking party to prove: (1) the underlying communication is protected by attorney-client privilege; (2) the parties had a common interest at the time the information was disclosed; (3) the information was shared in furtherance of that common interest; and (4) the parties have not waived the privilege. ${ }^{63}$ The privilege usually only applies where the clients are represented by separate counsel. ${ }^{64}$

Several issues arise when courts apply the common interest doctrine: (1) "What is a common interest?" (2) Does the common interest doctrine require pending or anticipated litigation? (3) Does the doctrine apply to communications made in the absence of counsel? (4) Does the common interest doctrine apply "absent a written confidentiality agreement?" (5) Who can waive the common interest doctrine protection? ${ }^{65}$ While each question has its own implications on the doctrine, this Comment focuses on

\footnotetext{
58. 2 N.W.2d at 416 .

59. Id. at $416-18$.

60. Id. at 417 .

61. Schaffzin, supra note 18 , at 59-60.

62. See Schaffzin, supra note 18 (discussing the common interest doctrine's lack of uniform application, and a proposal of uniformity).

63. RESTATEMENT (THIRD) OF THE LAW GOVERNING LAWYERS $§ 76$ (AM. LAW INST. 2000).

64. Teleglobe Commc'ns Corp. v. BCE, Inc. (In re Teleglobe Commc'ns Corp.), 493 F.3d 345, 365-69 (3d Cir. 2007) (distinguishing from the "co-client privilege"); see also Sunshine, supra note 14 , at $838-49,848$ tbl.1 (discussing differences between the common interest, joint defense, and co-client privileges).

65. Schaffzin, supra note 18 , at 69 .
} 
the two most discussed and inconsistently applied questions: What is a common interest, and does the doctrine apply in the absence of litigation?

\section{What Is a Common Interest?}

One issue courts face when applying the common interest doctrine is deciding what constitutes a "common interest." ${ }^{.66}$ Courts generally agree that the interest must be legal, as opposed to solely commercial. ${ }^{67}$ However, the agreement ends there. Jurisdictions vary substantially, even on what constitutes a "legal" interest-some courts require an identical legal interest, while others only require a similar legal interest. ${ }^{68}$

The definition of "legal interest" varies by jurisdiction. ${ }^{69}$ Courts requiring an identical legal interest vary on what constitutes "identical." Strict interpreters have only applied the common interest doctrine where parties are aligned on the same side of litigation, such as co-plaintiffs or codefendants. ${ }^{71}$ However, other courts have found parties' interests "identical" when the parties have an "identical legal interest" regarding the subject matter of the privileged communication, such as the enforcement or validity of a patent. ${ }^{72}$ Courts employing a broader common interest doctrine may

66. See, e.g., Niagara Mohawk Power Corp. v. Megan-Racine Assocs., Inc. (In re MeganRacine Assocs., Inc.), 189 B.R. 562, 573 (Bankr. N.D.N.Y. 1995) ("A common legal interest exists where the parties asserting the privilege were co-parties to litigation or reasonably believed that they could be made a party to litigation." (emphasis added)); Duplan Corp. v. Deering Milliken, Inc., 397 F. Supp. 1146, 1172 (D.S.C. 1975) ("A community of interest exists among different persons or separate corporations where they have an identical legal interest with respect to the subject matter of a communication between an attorney and a client concerning legal advice." (emphasis added)).

67. Duplan Corp., 397 F. Supp. at 1172 . The leading test for what constitutes a common interest was laid out in Duplan Corp. v. Deering Milliken Inc.:

A community of interest exists among different persons or separate corporations where they have an identical legal interest with respect to the subject matter of a communication between an attorney and a client concerning legal advice. The third parties receiving copies of the communication and claiming a community of interest may be distinct legal entities from the client receiving the legal advice and may be a non-party to any anticipated or pending litigation. The key consideration is that the nature of the interest be identical, not similar, and be legal, not solely commercial. The fact that there may be an overlap of a commercial and a legal interest for a third party does not negate the effect of the legal interest in establishing a community of interest.

Id. at 1172

68. Schaffzin, supra note 18 , at 69-73.

69. See infra notes $70-74$ and accompanying text.

70. See infra notes 71-72 and accompanying text.

71. See, e.g., United States ex rel. [Redacted] v. [Redacted], 209 F.R.D. 475, 479 (D. Utah 2001) (quoting NL Indus. v. Commercial Union Ins. Co., 144 F.R.D. 225, 230-31 (D.N.J. 1992)) ("A community of interest exists where different persons or entities "have an identical legal interest with respect to the subject matter of a communication between an attorney and a client concerning legal advice."').

72. E.g., Tenneco Packaging Specialty \& Consumer Prods., Inc. v. S.C. Johnson \& Son, Inc., 
only require a "substantially similar" interest. ${ }^{73}$ Some courts have even found a common interest where parties are engaged in adverse litigation. ${ }^{74}$ Thus, while courts generally require the parties to share a "legal interest," how that requirement is interpreted varies and is jurisdictionally dependent.

There are some situations where the interest is purely commercial, and thus, the common interest doctrine does not apply. In Cavallaro v. United States, two companies owned by the same family merged, and the merged entity sold for a substantial amount. ${ }^{75}$ The IRS investigated, suspecting the family overvalued the company to conceal a post-merger gift to their sons. ${ }^{76}$ As part of the investigation, the IRS issued a summons to the defendant's accounting firm who provided pre-merger tax advice. ${ }^{77}$ The family argued the communications were protected by attorney-client privilege because the accountant aided the law firm that provided legal advice concerning tax and merger issues. ${ }^{78}$ The First Circuit held the communications were not privileged, reasoning: "[T]he accountant does not share an interest in receiving legal advice from the lawyer and cannot logically be said to have an interest in common with the represented party or parties." ${ }^{, 79}$

How jurisdictions interpret or define "interest" can make or break parties' invocation of the common interest doctrine. ${ }^{80}$ Therefore, parties must understand their jurisdiction's definition of interest and ensure they meet the requisite definition before relying on the common interest doctrine. $^{81}$

\section{Is Pending or Anticipated Litigation Required?}

Courts routinely disagree on whether the common interest doctrine applies absent pending or current litigation. ${ }^{82}$ Generally, the requirement of

No. 98 C 2679, 1999 WL 754748, at *2 (N.D. Ill. Sept. 14, 1999).

73. E.g., In re Leslie Controls, Inc., 437 B.R. 493, 496 (Bankr. D. Del. 2010) (quoting Teleglobe Commc'ns Corp. v. BCE, Inc. (In re Teleglobe Commc'ns Corp.), 493 F.3d 345, 365 (3d Cir. 2007)).

74. See, e.g., Visual Scene, Inc. v. Pilkington Bros., 508 So. 2d 437, 441 (Fla. Dist. Ct. App. 1987).

75. 284 F.3d 236, 239 (1st Cir. 2002).

76. Id.

77. Id.

78. Id.

79. Id. at 250

80. See discussion infra Section II.E.

81. See discussion infra Section II.E.

82. At least eleven states have restricted the common interest doctrine to communications made in furtherance of ongoing litigation through rule or statute. See ARK. R. EVID. 502(b)(3); HAW. R. EVID. 503(b)(3); KY. R. EVID. 503(b)(3); ME. R. EVID. 502(b)(3); MISS. R. EVID. 502(b)(3); N.H. R. EviD. 502(b)(3); N.D. R. Evid. 502(b)(3); OKLA. STAT. ANN. tit. 12, § 2502(B)(3) (West 2009 \& 
pending or anticipated litigation aligns with how the court defines a common interest. The more identical the court requires the interest to be, the more likely it is to require pending or anticipated litigation. Courts requiring anticipated litigation reason that no common legal interest can exist without the threat of actual litigation. ${ }^{83}$ Conversely, courts that do not require pending or anticipated litigation believe that common legal interests can exist outside the scope of litigation. ${ }^{84}$ This lack of the common interest doctrine's uniform application frustrates the purpose of attorney-client privilege by creating uncertainty about what communications will remain privileged. ${ }^{85}$

\section{a. Two Competing Viewpoints: An Illustration of the Doctrine's Application to Communications Made in the Course of a Merger and Acquisition}

Jurisdictions generally take one of two competing viewpoints on whether the common interest doctrine applies to communications made absent pending or anticipated litigation, such as communications made during the due diligence period of mergers, acquisitions, or similarly substantial transactions. ${ }^{86}$ Whether the jurisdiction required pending or anticipated litigation was a determinative factor in both Ambac Assurance Corp. v. Countrywide Home Loans ${ }^{87}$ and Hewlett-Packard v. Bausch \& $L o m b,{ }^{88}$ and led to substantially different results.

Supp. 2014); S.D. Codified Laws $\S 19-19-502(b)(3)$ (Westlaw through 2016 Reg. Sess.); TeX. R. EVID. 503(b)(1)(C); VT. R. EVID. 502(b)(3). Other jurisdictions have embraced the same limitation through judicial decision. See, e.g., In re Santa Fe Int'l Corp., 272 F.3d 705, 711 (5th Cir. 2001); O'Boyle v. Borough of Longport, 94 A.3d 299, 304, 317 (N.J. 2014); Boyd v. Comdata Network, Inc., 88 S.W.3d 203, 214-15 (Tenn. Ct. App. 2002); Gallagher v. Office of Attorney Gen., 787 A.2d 777, 784-85 (Md. 2001); Hicks v. Commonwealth, 439 S.E.2d 414, 416 (Va. Ct. App. 1994); Visual Scene, Inc. v. Pilkington Bros., 508 So. 2d 437, 440-41 (Fla. Dist. Ct. App. 1987).

83. Schaffzin, supra note 18 , at 74 .

84. See Schaeffler v. United States, 806 F.3d 34, 40 (2d Cir. 2015) (citing United States v. Schwimmer, 892 F.2d 237, 243 (2d Cir. 1989)); United States v. BDO Seidman, LLP, 492 F.3d 806, 816, 816 n.6 (7th Cir. 2007); Teleglobe Commc'ns Corp. v. BCE, Inc. (In re Teleglobe Commc'ns Corp.), 493 F.3d 345, 364-66 (3d Cir. 2007); In re Regents of the Univ. of Cal., 101 F.3d 1386, 1390-1391 (Fed. Cir. 1996); United States v. Zolin, 809 F.2d 1411, 1417 (9th Cir. 1987), aff'd in part, vacated in part, 491 U.S. 554 (1989); Hanover Ins. Co. v. Rapo \& Jepsen Ins. Servs., Inc., 870 N.E.2d 1105, 1110-12 (Mass. 2007); Santa Fe Pac. Gold Corp. v. United Nuclear Corp., 175 P.3d 309, 316 (N.M. Ct. App. 2007).

85. Schaffzin, supra note 18 , at 53-54, 66 .

86. See Ambac Assurance Corp. v. Countrywide Home Loans, Inc., 57 N.E.3d 30, 39-40 (N.Y. 2016). But see Hewlett-Packard Co. v. Bausch \& Lomb, Inc., 115 F.R.D. 308, 310-12 (N.D. Cal. 1987).

87. 57 N.E.3d 30 (N.Y. 2016).

88. 115 F.R.D. 308 (N.D. Cal. 1987). 
In Ambac Assurance Corp. v. Countrywide Home Loans, New York's highest court declined to apply the common interest doctrine to communications between parties to a merger and acquisition. ${ }^{89}$ The issue was whether defendant Bank of America was required to disclose a series of communications with defendant Countrywide Financial during the due diligence period of the companies' 2008 merger. ${ }^{90}$ Plaintiff Ambac Assurance Corporation claimed Countrywide had fraudulently misrepresented the quality of the mortgage loans issued by Countrywide, and because of Countrywide's merger with Bank of America, Bank of America was responsible for Countrywide's liability. ${ }^{91}$

During discovery, Bank of America withheld the communications, claiming that they were protected by the common interest doctrine because they pertained to legal issues connected with completing the merger. ${ }^{92}$ Ambac argued that the voluntary sharing of confidential communications prior to the merger's closing waived attorney-client privilege because it did not relate to pending or anticipated litigation. ${ }^{93}$ Reversing the appellate decision, a divided four-two court held that the common interest doctrine did not apply absent pending or anticipated litigation, reasoning:

[A]ny benefits that may attend . . . an expansion of the doctrine are outweighed by the substantial loss of relevant evidence, as well as the potential for abuse. The difficulty of defining "common legal interests" outside the context of litigation could result in the loss of evidence of a wide range of communications between parties who assert common legal interests but who really have only non-legal or exclusively business interests to protect. $^{94}$

The majority noted that New York's formulation is "limited to situations where the benefit and the necessity of shared communications are at their highest, and the potential for misuse is minimal." ${ }^{95}$ On the other hand, Judge Jenny Rivera, joined in the dissent by Judge Michael Garcia, reasoned that the "better rule is grounded not in the rote application of a litigation requirement, but in the legal dynamics of a modern corporate transactional practice. $" 96$

\footnotetext{
89. 57 N.E.3d at $32,37$.

90. See id. at 32-35 (Countrywide became a wholly-owned subsidiary of Bank of America post-merger).

91. Id. at 32 .

92. Id. at 32-33.

93. Id. at 33 .

94. Id. at 38 .

95. Id. at 37 .

96. Id. at 43 (Rivera, J., dissenting).
} 
In Hewlett-Packard Co. v. Bausch \& Lomb, Inc., the Northern District of California reached the opposite conclusion in a patent law context. ${ }^{97}$ Bausch \& Lomb shared a privileged patent opinion letter with a potential buyer of one of its divisions. ${ }^{98}$ The letter concerned whether one of HewlettPackard's patents was valid, and whether Bausch \& Lomb may have infringed on the patent. ${ }^{99}$ Hewlett-Packard claimed this communication waived attorney-client privilege. ${ }^{100}$ Bausch \& Lomb contended, however, it disclosed the letter in anticipation of litigation because there was a real possibility that the third party would buy the division, and then that both Bausch \& Lomb and the third party could face litigation with HewlettPackard over the subject patent. ${ }^{101}$ The third party did not buy the division, therefore only Bausch \& Lomb faced litigation over the patent. ${ }^{102}$ Regardless, the court held privilege was not waived. ${ }^{103}$ Bausch \& Lomb took substantial steps to ensure the potential buyer maintained the letter's confidentiality: only two copies were made, the buyer was instructed no further copies were to be made, both copies were returned to Bausch \& Lomb, and the letter was not disclosed to others. ${ }^{104}$

While the court noted that, at the time the communication was made, joint litigation could be plausibly anticipated, the court relied more heavily on public policy concerns weighing against the finding of waiver:

[E]xpansive definitions of waiver can pressure lawyers to claim privilege on documents that they would otherwise disclose and to litigate tenaciously the resulting discovery disputes all because the risks of inadvertent waiver are so great. Thus expansive waiver doctrine increases the cost of litigation to the parties and increases the number of discovery disputes courts must resolve. Moreover, the risk of waiver can create an advantage for those litigants who can afford the massive expenditures often required to protect against waiver. ${ }^{105}$

Reasoning that the principal purpose of waiver should be to protect against parties who use privilege unfairly, the court distinguished between "partial" and "selective" disclosure. ${ }^{106}$ Partial disclosure occurs when a party uses

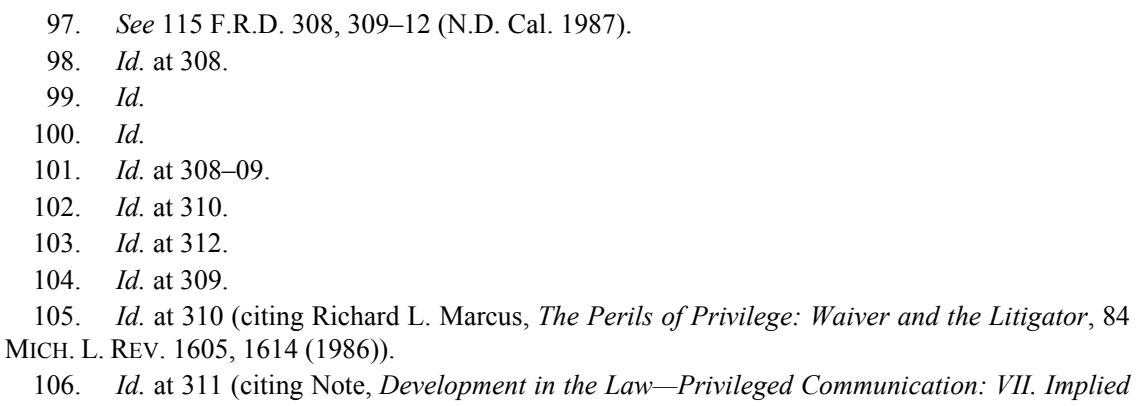


"advantageous portions of the privileged material," while claiming privilege on portions that may be detrimental to their case. ${ }^{107}$ Selective disclosure occurs when a party, like Bausch \& Lomb did here, "shares an entire document with a select[], limited audience."108 The court reasoned that, "[t]hese kinds of disclosures generally leave the adverse party in no worse position than if no disclosure had taken place and, therefore, create no fairness issue." 109

In holding that Bausch \& Lomb had not waived attorney-client privilege when it shared the document, the court reasoned:

Legal doctrine that impedes frank communication between buyers and sellers also sets the stage for more lawsuits, as buyers are more likely to be unpleasantly surprised by what they receive. By refusing to find waiver in these settings courts create an environment in which businesses can share more freely information that is relevant to their transactions. This policy lubricates business deals and encourages more openness in transactions of this nature. ${ }^{110}$

The Hewlett-Packard court's concerns about waiver's impact on business transactions took the opposite position from the Ambac court.

As illustrated by Hewlett-Packard and Ambac, whether the jurisdiction requires litigation leads to an entirely different result in factually similar situations. As the court noted in Hewlett-Packard, a finding of wavier in these situations can have grave impacts not only on the parties involved, but in the larger economic scheme as well. ${ }^{111}$

\section{E. The National Spectrum}

An overwhelming majority of states have concluded that attorney-client privilege is not waived when privileged information is shared with coparties. ${ }^{112}$ In federal courts, the common interest doctrine is "well recognized in all circuits that have considered it." "113 As courts separately determined how to define the common interest doctrine's elements, a variety

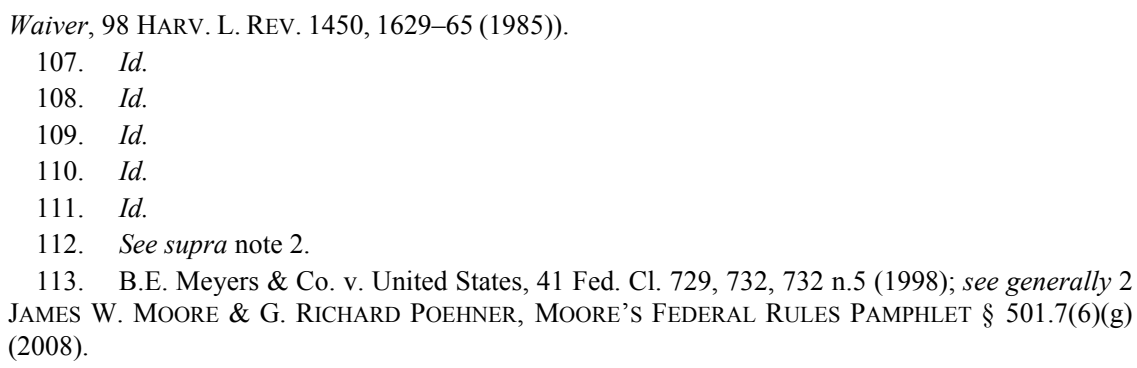

113. B.E. Meyers \& Co. v. United States, 41 Fed. Cl. 729, 732, 732 n.5 (1998); see generally 2 James W. MoOre \& G. Richard Poehner, MoOre's Federal Rules Pamphlet $\S 501.7(6)(\mathrm{g})$ (2008). 
of applications arose. ${ }^{114}$ Jurisdictions generally fall into three categories: (1) they recognize the common interest doctrine and require pending or anticipated litigation; (2) they recognize the common interest doctrine and do not require pending or anticipated litigation - these jurisdictions are most likely to apply the common interest doctrine in transactional situations; (3) they do not recognize the common interest doctrine at all. ${ }^{115}$ Of the jurisdictions that recognize the doctrine, some have codified their approach while others have left it to common law. ${ }^{116}$ This section provides an overview of the national spectrum as it sits today from broad applicationMassachusetts and Delaware- to narrow-New York and Texas.

The Restatement of the Law Governing Lawyers recognizes the broadest version of the common interest doctrine:

If two or more clients with a common interest in a litigated or nonlitigated matter are represented by separate lawyers and they agree to exchange information concerning the matter, a communication of any such client that otherwise qualifies as privileged under $\S \S 68-72$ that relates to the matter is privileged as against third persons. Any such client may invoke the privilege, unless it has been waived by the client who made the communication.

The Restatement's formulation is broad enough that it recognizes the privilege as used by co-defendants in both criminal and civil suits as well as in mergers and transactions between entities. ${ }^{118}$ However, Massachusetts is the only state that has adopted the Restatement version. ${ }^{119}$

Delaware also employs a broad version of the common interest doctrine as codified in Delaware Rule of Evidence 502(b)(3). ${ }^{120}$ The Delaware statute is modeled after Proposed Federal Rule of Evidence 503, which, while not enacted, has provided a model for many jurisdictions choosing to

114. See infra notes $115-39$ and accompanying text.

115. See supra notes 1-4 and accompany text; Section II.D.2.

116. See Amended Brief \& Cross-Appeal, supra note 2, at *21-23 (citing cases).

117. RESTATEMENT (THIRD) OF THE LAW GOVERNing LAWYers § 76(1) (AM. LAW INST. 2000) (emphasis added).

118. See id. at $\S 76 \mathrm{cmt}$. c ("Exchanging communications may be predicated on an express agreement, but formality is not required. It may pertain to litigation or to other matters.").

119. Hanover Ins. Co. v. Rapo \& Jepsen Ins. Servs., Inc., 870 N.E.2d 1105, 1110, 1112 (Mass. 2007); Matthew D. LaBrie, The Common Interest Privilege, AM. BAR Ass'N (Sept. 30, 2014), https://apps.americanbar.org/litigation/committees/trialevidence/articles/fall2014-0914-commoninterest-privilege.html.

120. See DEL. R. Evid. 502(b)(3) (“A client has a privilege to refuse to disclose and to prevent any other person from disclosing confidential communications made for the purpose of facilitating the rendition of professional legal services to the client ... by the client or the client's representative or the client's lawyer or a representative of the lawyer to a lawyer or a representative of a lawyer representing another in a matter of common interest ...."). 
adopt a broader interpretation of the common interest doctrine. ${ }^{121}$ Actual or pending litigation is not required under the rule or statutory definition, however, in some situations parties may need to at least anticipate litigation. ${ }^{122}$ Delaware courts have extended the doctrine to communications in business transactions as long as the communications concern actual legal advice. $^{123}$ "Actual legal advice" includes communications about legal advice for business matters, regulatory matters, and compliance, but not communications dealing primarily with business interests. ${ }^{124}$

Each federal circuit recognizes some form of the common interest doctrine. ${ }^{125}$ The federal common interest doctrine generally leans towards a broader interpretation, and the majority of federal circuits and some state courts that have addressed the issue do not require pending or anticipated litigation. ${ }^{126}$ However, the Fifth Circuit Court of Appeals has expressly required anticipated or pending litigation. ${ }^{127}$

121. See H.R. 5463, 93rd Cong., at 19 (1st Sess. 1973); 1975 FRE Original Enactment Legislative History Page: Congressional Timeline, FED. EVID. REV., http://federalevidence.com/pdf/FRE_Amendments/1975_Orig_Enact/HR\%205463\%20\%281973\%2 $9 \% 20 \% 28$ culminating $\% 20 \mathrm{in} \% 201975 \% 20$ enactment $\% 29$.pdf (last visited Apr. 1, 2017) (providing a PDF copy of the 1973 amendment); see, e.g., NEB. REV. STAT. § 27-503(2)(c) (West 2009); NeV. REV. STAT. § 49.095(3) (West 2004); OR. REV. Stat. § 40.225(2)(c) (Supp. 2014); Wis. STAT. ANN. $\S$ 905.03(2) (West Supp. 2013); ALASKa R. Evid. 503(b)(3); DEL. R. EVID. 502(b)(3); N.M. R. EVID. 11-503(B)(3).

122. See In re Lululemon Athletica Inc. 220 Litig., C.A. No. 9039-VCP, 2015 WL 1957196, at *9 (Del. Ch. Apr. 30, 2015) (holding two parties "coordinat[ing] a statement" in responding to a Wall Street Journal inquiry shared a common legal interest, and anticipated litigation at the time they shared the privileged communications); Titan Inv. Fund II, LP v. Freedom Mortg. Corp., C.A. No. 09C-10-259 WCC, 2011 WL 532011, at *4-5 (Del. Super. Ct. Feb. 2, 2011) (holding two parties negotiating a potential commercial agreement at arm's length did not have a common interest because their interests were adverse, they failed to assert a clear legal interest, and nothing suggested that the parties anticipated becoming parties to litigation at the time they shared legal advice).

123. See Am. Legacy Found. v. Lorollard Tobacco Co., No. Civ. A. 19406, 2004 WL 2521289, at *3-5 (Del. Ch. Nov. 3, 2004).

124. See Glassman v. Crossfit, Inc., No. 7717-VCG, 2012 WL 4859125, *3-4 (Del. Ch. Oct. 12, 2012) (citing Titan Inv. Fund, 2011 WL 532011, at*4).

125. See, e.g., United States v. Gonzalez, 669 F.3d 974, 979-81 (9th Cir. 2012); United States v. BDO Seidman, LLP, 492 F.3d 806, 814-18 (7th Cir. 2007); Teleglobe Commc'ns Corp. v. BCE, Inc. (In re Teleglobe Commc'ns Corp.), 493 F.3d 345, 362-66 (3d Cir. 2007); United States v. Almeida, 341 F.3d 1318, 1323-27 (11th Cir. 2003); Cavallaro v. United States, 284 F.3d 236, 24951 (1st Cir. 2002); In re Santa Fe Int'l Corp., 272 F.3d 705, 708-13 (5th Cir. 2001); In re IPCOM GMBH \& Co., KG, 428 Fed. App'x. 984, 986 (D.C. Cir. 2001); Frontier Roofing, Inc. v. GormanRupp Co., Inc., 136 F.3d 695, 705 (10th Cir. 1998); In re Grand Jury Subpoena Duces Tecum, 112 F.3d 910, 922 (8th Cir.1997); In re Regents of Univ. of Cal., 101 F.3d 1386, 1389-91 (Fed. Cir. 1996); In re Grand Jury Subpoenas, 89-3 \& 89-4, John Doe 89-129, 902 F.2d 244, 248-49 (4th Cir. 1990); United States v. Schwimmer, 892 F.2d 237, $243-45$ (2d Cir. 1989); Cooey v. Strickland, 269 F.R.D. 643, 652-53 (S.D. Ohio 2010) (citing Reed v. Baxter, 134 F.3d 351, 356 (6th Cir. 1998)).

126. See, e.g., Ambac Assurance Corp. v. Countrywide Home Loans, Inc., 57 N.E.3d 30, 850 51, 851 n.1 (N.Y. 2016) (Rivera, J., dissenting); see also Schaeffler v. United States, 806 F.3d 34, 40 (2d Cir. 2015) (citing Schwimmer, 892 F.3d at 243); BDO Seidman, LLP, 492 F.3d at 816; In re Teleglobe Commc'ns Corp., 493 F.3d at 360-65; In re Regents, 101 F.3d at 1390-91; United States 
On the other end of the spectrum, New York employs a strict interpretation of the common interest doctrine. ${ }^{128}$ Unlike Delaware and Massachusetts, New York has not codified its common interest doctrine. However, New York case law restricts its doctrine to civil and criminal matters, co-plaintiffs and co-defendants, and only in the context of pending or reasonably anticipated litigation. ${ }^{129}$ New York courts have uniformly rejected attempts at expanding the common interest doctrine to communications that do not involve pending or reasonably anticipated litigation. ${ }^{130}$ In Ambac Assurance Corp. v. Countrywide Home Loans, Inc., as previously discussed, New York's highest court declined to apply the doctrine in the merger context, reasoning: "when businesses share a common interest in closing a complex transaction, their shared interest in the transaction's completion is already an adequate incentive for exchanging information necessary to achieve that end." ${ }^{\prime 31}$ The court further opined that any benefit reaped by the extension of the doctrine is outweighed by the loss of relevant evidence and potential for abuse. ${ }^{132}$

Similarly, Texas employs a narrow version of the common interest doctrine and has codified it as such. ${ }^{133}$ Texas Rule of Evidence 503(b)(1)(C) extends attorney-client privilege to communications concerning a matter of common interest in the pending action. ${ }^{134}$ To align with this statutory definition, Texas courts refer to the doctrine as the "allied litigant doctrine" as opposed to the common interest doctrine. ${ }^{135}$ Texas, similar to New York, sought to limit the privilege to situations where the benefit and necessity are

v. Zolin, 809 F.2d 1411, 1417 (9th Cir. 1987) ("Even where the non-party . . . faces no immediate liability, it can still be found to have a common interest with the party seeking to protect the communications."), aff'd in part, vacated in part, 491 U.S. 554 (1989).

127. BDO Seidman, LLP, 492 F.3d at 816 n.6 (citing to cases in the First, Second, Fourth, Ninth, and Federal Circuits, and noting that only the Fifth Circuit has held that at least a threat of litigation is necessary); In re Santa Fe, 272 F.3d at 711 ("[I]n looking at other cases discussing the [common interest] privilege in this circuit, it appears that there must be a palpable threat of litigation at the time of the communication, rather than a mere awareness that one's questionable conduct might some day result in litigation, before communications . . . could qualify for protection.").

128. See Ambac, 57 N.E.3d at 37-40.

129. Id. at 37 .

130. See id.; Hyatt v. State of Cal. Franchise Tax Bd., 962 N.Y.S.2d 282, 295-97 (N.Y. App. Div. 2013); Hudson Valley Marine, Inc. v. Town of Cortlandt, 816 N.Y.S.2d 183, 184 (N.Y. App. Div. 2006); Yemini v. Goldberg, 821 N.Y.S.2d 384, 387 (N.Y. App. Div. 2006) (quoting Aetna Cas. \& Sur. Co. v. Certain Underwriters at Lloyd's London, 676 N.Y.S.2d 727, 732 (N.Y. Sup. Ct. 1998)).

131. Ambac, 57 N.E.3d at 38 .

132. Id.

133. See TEX. R. EvID. 503(b)(1)(C).

134. Id. (emphasis added)

135. In re XL Specialty Ins. Co., 373 S.W.3d 46, 51-53 (Tex. 2012). 
at their highest while also "restrict[ing] the opportunity for misuse."136 The allied litigation doctrine also only applies to communications "between a client, or the client's lawyer, to another party's lawyer, [but] not the other party itself." 137

While the national spectrum varies, it trends towards recognition of the common interest doctrine in some form. ${ }^{138}$ Kansas is in the minority of states that do not yet recognize any form of the doctrine. ${ }^{139}$

\section{F. The Uncertainty of the Common Interest Doctrine in Kansas}

Kansas does not yet recognize the common interest doctrine in any form. ${ }^{140}$ The Kansas Rules of Evidence lay out Kansas's attorney-client privilege law and its exceptions, but do not explicitly recognize either the joint defense or the common interest doctrine. ${ }^{141}$ The 1984 criminal case State v. Maxwell ${ }^{142}$ is the only Kansas state court case truly discussing the joint defense doctrine and, while it appears to recognize the joint defense doctrine, more recent cases have questioned its validity. ${ }^{143}$ Although the common interest doctrine is regularly applied in Kansas federal courts, no state court has discussed or applied the doctrine. ${ }^{144}$

\section{The Joint Defense Doctrine in Kansas}

Kansas appears to recognize the common interest doctrine's predecessor - the joint defense doctrine. ${ }^{145}$ Under Kansas's attorney-client privilege statute, Kansas Statutes Annotated (K.S.A.) section 60-426(b)(5), attorney-client privilege does not apply to a communication "relevant to a matter of common interest between two or more clients if made by any of them to an attorney whom they have retained in common when offered in an action between any of such clients." Arguably this exception recognizes a joint client or joint defense privilege (for two or more clients sharing the same attorney) because without such a privilege this exception would be

136. Id. at 52 (quoting United States v. Duke Energy Corp., 214 F.R.D. 383, 388 (M.D.N.C. 2003)).

137. Id. at 52-53.

138. See supra notes 112-37 and accompanying text.

139. See infra notes $163-78$ and accompanying text.

140. See discussion infra Section II.F.2.

141. KAN. StAT. ANN. § 60-426 (Supp. 2016).

142. 691 P.2d 1316, 1320 (Kan. Ct. App. 1984).

143. See discussion infra Sections II.F.1-2.

144. See discussion infra Section II.F.2.

145. See $\S 60-426(b)(5)$. 
unnecessary. However, the courts have not confirmed or denied such an argument, and there is limited case law on the subject, with Kansas courts only discussing the doctrine in two cases. ${ }^{146}$

The Kansas Court of Appeals first applied the joint defense privilege in the criminal context in the 1984 case, State v. Maxwell. ${ }^{147}$ Defendant Johnny Maxwell previously shared counsel with two other defendants, and, at trial, the other defendants testified against Maxwell. ${ }^{148}$ Maxwell sought to admit evidence that this trial testimony was inconsistent with prior statements made in the presence of their common counsel. ${ }^{149}$ The trial court found that the attorney-client privilege applied to these statements and refused to admit the statements. ${ }^{150}$

On appeal, Maxwell argued that attorney-client privilege was waived because the statements were made in the presence of all the defendants, and, in the alternative, if the statements were privileged, the privilege was waived when original counsel disclosed the information to the assistant district attorney. ${ }^{151}$ The Court of Appeals disagreed, and in affirming the trial court, recognized the joint defense privilege:

Where two or more persons jointly consult an attorney concerning mutual concerns, their confidential communications with the attorney, although known to each other, will be privileged in controversies of either or both of the clients with the outside world.

$\cdots$

The joint defense privilege encompasses shared communications "to the extent that they concern common issues and are intended to facilitate representation in possible subsequent proceedings." It is also essential that the codefendants have exchanged the information in confidence, "not ... for the purpose of allowing unlimited publication and use, but rather ... for the limited purpose of assisting in their common cause." $" 152$

146. See Associated Wholesale Grocers, Inc. v. Americold Corp., 975 P.2d 231, 239 (Kan. 1999); Maxwell, 691 P.2d at 1320-21.

147. 691 P.2d at $1320-22$.

148. Id. at 1319 .

149. Id.

150. Id. at $1319-21$.

151. Id. at 1319 .

152. Id. at 1320, 1321 (citations omitted) (first citing Ohio-Sealy Mattress Mfg. Co. v. Kaplan, 90 F.R.D. 21, 29 (N.D. Ill. 1980); then quoting Hunydee v. United States, 355 F.2d 183, 185 (9th Cir. 1965); and then quoting Wilson P. Abraham Const. Corp. v. Armco Steel Corp., 559 F.2d 250, 253 (5th Cir. 1977)). 
Furthermore, when a third party seeks to have those communications disclosed, none of the clients - not even a majority-can waive the privilege. ${ }^{153}$ However, the facts in Maxwell limited the holding to situations where multiple criminal defendants were commonly represented by one attorney. ${ }^{154}$

Since Maxwell, the joint defense doctrine has been rarely mentioned, and never fully discussed, in a Kansas state court case. Fifteen years after Maxwell, the Kansas Supreme Court declined to rule on the joint defense doctrine in the civil case Associated Wholesale Grocers v. Americold Corp. ${ }^{155}$ Although the parties referenced the joint defense doctrine in their briefs, the court declined to address it because none of the experts, parties, nor the district court referenced the statutory attorney-client privilege in K.S.A. section 60-426. ${ }^{156}$ However, the court questioned the validity of the doctrine: "Without a credible argument for recognition of the joint defense doctrine based on the language of the attorney-client privilege statute itself [K.S.A. section 60-426] proponents of the joint defense doctrine are vulnerable to attack." 157

However, federal courts applying Kansas law have seemingly extended the Kansas state courts' version of the joint defense doctrine. In the civil case Burton v. R.J. Reynolds Tobacco Co., Judge John W. Lungstrum relied on Maxwell in holding that certain documents sought in discovery were privileged. $^{158}$ Defendants were members of the Council for Tobacco Research (CTR), along with other members of the tobacco industry, and were represented by separate counsel. ${ }^{159}$ In discovery, plaintiff "sought all documents relat[ed] to the CTR special projects" but defendant claimed the documents were protected by attorney-client privilege under the joint defense doctrine. ${ }^{160}$ The court agreed with defendant in holding the joint defense doctrine includes "shared communications to the extent that they concern common issues and are intended to facilitate representation in possible subsequent proceedings." 161 However, the information must have been shared in confidence solely for assisting the common cause. ${ }^{162}$

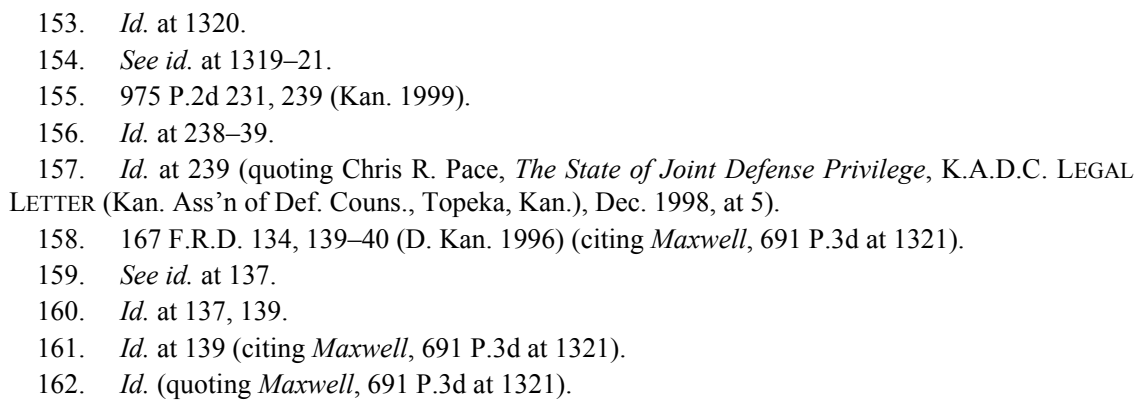


The status of joint defense doctrine in Kansas is uncertain to say the least. As the common interest doctrine's predecessor, this uncertainty leaves the common interest doctrine on unsteady ground.

\section{The Common Interest Doctrine in Kansas}

The common interest doctrine is currently non-existent under Kansas state law. The Kansas Rules of Evidence are silent on the common interest doctrine and Kansas state courts have rarely mentioned it, never discussing it in detail or applying it. Alternatively, Kansas federal courts have embraced the doctrine.

While Kansas state courts have never fully discussed the common interest doctrine, the Kansas Court of Appeals briefly addressed it in Smith v. Philip Morris Cos. ${ }^{163}$ Smith brought a class action against a number of tobacco companies claiming they were conspiring to fix cigarette prices in Kansas. ${ }^{164}$ Discovery disputes over whether the joint-defense privilege is recognized under Kansas law prompted the court to appoint Special Master Judge Buchanan. ${ }^{165}$ The trial court concluded that Special Master Judge Buchanan correctly applied Kansas law when he ruled that privilege was waived when communications were shared with jointly-aligned co-parties. ${ }^{166}$ In doing so, Buchanan rejected both the joint defense doctrine and the common interest doctrine. ${ }^{167}$ Ironically, the trial court cited State v. Maxwell and Associated Wholesale Grocers in supporting a rejection of the doctrine. ${ }^{168}$ Defendants sought review of the trial court's order by filing a petition for writ of mandamus to the Kansas Supreme Court. ${ }^{169}$ Numerous groups filed amicus briefs arguing Judge Smith's ruling was erroneous on the common interest doctrine issue. ${ }^{170}$ The Kansas Supreme Court issued an

163. See 335 P.3d 644, 661-62 (Kan. Ct. App. 2014); Amended Brief \& Cross-Appeal, supra note 2 , at $* 17-24$.

164. Amended Brief \& Cross-Appeal, supra note 2, at*1-3; Smith, 335 P.3d at 650.

165. Smith, 335 P.3d at 661 .

166. See Amended Brief \& Cross-Appeal, supra note 2, at *15.

167. See id.

168. See Amicus Curiae Brief of the Kansas Ass'n of Defense Counsel, Philip Morris USA Inc. v. Twenty-Sixth Judicial District Court of Seward County (Smith), No. 07-99546-S (Kan. Mar. 13, 2008), 2008 WL 1724166, at *11 [hereinafter Amicus Brief of the KADC]; Greg A. Drumwright \& Michael G. Jones, KADC Files Amicus Brief in Support of Joint Defense and Common Interest Privilege, KAN. DEF. J., Spring 2008, at 3, http://www.kadc.org/Portals/0/Content_Newsletter/08Spring.pdf.

169. Amended Brief \& Cross-Appeal, supra note 2, at *16; Drumwright \& Jones, supra note 168, at 3. See also Phillip Morris USA Inc. v. Twenty-Sixth Judicial District Court of Seward County (Smith), No. 99,546 (Kan. Apr. 24, 2008).

170. See, e.g., Amicus Brief of the KADC, supra note 168; Brief of Amicus Curiae Product Liability Advisory Council, Inc. in Support of Petition for a Writ of Mandamus, Philip Morris USA 
order denying the defendants' petition for mandamus on procedural grounds in which it emphasized that it was not expressing an opinion on the validity of either the joint defense or common interest doctrine. ${ }^{171}$ In not flat-out rejecting the doctrines, the court preserved the issue for another day. ${ }^{172}$

Conversely, federal courts applying Kansas law recognize the common interest doctrine and have applied it on several occasions. In Sawyer v. Southwest Airlines, the United States District Court of Kansas did not find the lack of Kansas statutes or cases recognizing the common interest doctrine to be fatal. ${ }^{173}$ Southwest shared documents with its insurer, Global, and Sawyer claimed this waived attorney-client privilege. ${ }^{174}$ Southwest argued this was not a waiver because Global was a client of the same attorney, and Global's claims attorney requested legal advice in the matter. ${ }^{175}$ The court noted it did not matter whether the court applied Kansas or federal attorney-client privilege law because the law is the same under both. ${ }^{176}$ Magistrate Judge Waxse found that Southwest met the elements of the common interest doctrine, and held that for the doctrine to attach, the two parties must share a common interest in "securing legal advice related to the same matter - and that the communications [must] be made to advance" the common interest. ${ }^{177}$ Further, "the nature of the interest [must] be identical, not similar, and be legal, not solely commercial." ${ }^{, 178}$ Thus, while the common interest doctrine is alive and well in Kansas federal courts, Kansas state courts' failure to recognize the doctrine leaves attorneys and parties uncertain about what communications may waive or retain attorney-client privilege and disadvantages them as compared to other jurisdictions.

Inc. v. Twenty-Sixth Judicial District Court of Seward County (Smith), No. 07-99546-S, (Kan. Mar. 12, 2008), 2008 WL 1724167 [hereinafter Amicus Brief for Product Liability Advisory Council].

171. See Drumwright \& Jones, supra note 168, at 3; Amended Brief \& Cross-Appeal, supra note 2, at *20-24. See also Phillip Morris USA Inc. v. Twenty-Sixth Judicial District Court of Seward County (Smith), No. 99,546 (Kan. Apr. 24, 2008).

172. Drumwright \& Jones, supra note 168, at 3.

173. Sawyer v. Sw. Airlines, Nos. Civ.A.01-2385-KHV, Civ.A.01-2386-KHV, 2002 WL 31928442, at *3-4 (D. Kan. Dec. 23, 2002) (holding the common interest doctrine was satisfied because Global's claims attorney retained Southwest's attorney to provide "legal advice in connection with all matters" related to the consolidated cases, and she also "requested and obtained legal advice from [Southwest's attorney] in connection with" related matters).

174. Id. at $* 1-3$.

175. Id. at $* 2$.

176. Id.

177. Id. at $* 3$ (quoting First Pac. Networks, Inc. v. Atl. Mut. Ins. Co., 163 F.R.D. 574, 581 (N.D. Cal. 1995)).

178. Id. (quoting Johnson Matthey, Inc. v. Research Corp. \& Research Corp. Techs, Inc., No. 01CIV.8115MBMFM, 2002 WL 1728566, *6 (S.D.N.Y. 2002)). 


\section{ANALYSIS}

While the common interest doctrine's jurisdictional inconsistency is far from ideal, Kansas's failure to recognize the doctrine in any form is especially problematic. Kansas should recognize the common interest doctrine to: provide clarity and certainty for Kansas attorneys and their clients; further the goals of attorney-client privilege; promote efficiency and eliminate unnecessary costs; and align itself with the national trend and highly persuasive courts. The means Kansas chooses is not as important as the ends, in that Kansas should recognize a form that is clearly defined, thus increasing the value of the doctrine and decreasing the risks.

To accomplish these goals, Kansas should recognize a fairly broad version of the common interest doctrine. The elements of an ideal Kansas common interest doctrine include: a communication otherwise protected by attorney-client privilege; made between two parties sharing a common legal interest; made in furtherance of the common interest; and that the privilege has not otherwise been waived.

While the common interest doctrine is ripe for discussion in Kansas courts, Kansas attorneys should be wary of relying on the doctrine in the meantime. However, there are a number of things Kansas attorneys can do to help sway the presumption toward privilege.

\section{A. Why Kansas Should Recognize the Common Interest Doctrine}

The current state of not only the common interest doctrine, but also the joint defense privilege in Kansas is highly unsettled. While State v. Maxwell appeared to explicitly recognize the joint defense privilege in at least the criminal context, ${ }^{179}$ Associated Wholesale Grocers and Philip Morris Cos. questioned the validity of or declined to apply the doctrines to the civil context. ${ }^{180}$ This uncertainty is problematic for attorneys, and unfair to their clients.

It creates a problematic conflict between Kansas law and the national trend. Moreover, it discourages parties from disclosing attorney-client privileged information to commonly interested parties and "undermines the goals of the attorney-client privilege" in addition to a less efficient and more expensive judicial system. ${ }^{181}$ A recognition of the common interest doctrine

179. 691 P.2d 1316, 1320-21 (Kan. Ct. App. 1984).

180. Associated Wholesale Grocers, Inc. v. Americold Corp., 975 P.2d 231, 238-39 (Kan. 1999); Smith v. Philip Morris Cos., 335 P.3d 644, 661-62 (Kan. Ct. App. 2008); see Amicus Brief of the KADC, supra note 168 , at *1.

181. Schaffzin, supra note 18 , at $66,85-90$. 
would clarify Kansas's attorney-client privilege statute and align Kansas law with highly persuasive courts-Kansas federal courts and Delaware. Kansas has long followed Delaware corporate law, and the United States District Court for the District of Kansas regularly applies Kansas state law. ${ }^{182}$ Both jurisdictions recognize a broad common interest doctrine and apply it regularly. ${ }^{183}$

As it currently stands, Kansas attorneys and their clients cannot be sure whether their case will be the one that the court finally decides to apply the common interest doctrine to, or whether their communication to a third party will waive attorney-client privilege. Recognizing the common interest doctrine would allow Kansas to serve the underlying purpose of attorneyclient privilege, and create fluidity with courts that Kansas aligns closely with. ${ }^{184}$

1. Failure to Recognize the Common Interest Doctrine Creates a Problematic Conflict for Kansas Attorneys and Parties

Kansas is one of the last jurisdictions to not recognize the common interest doctrine in some capacity, and as such, Kansas attorneys and parties are at a huge disadvantage under conflict of law principles. This is especially problematic in cases where similar lawsuits are pending, or have been filed in multiple states against the same defendants. ${ }^{185}$ Where "privilege is upheld by one body of law, but denied by [another]," problems arise. ${ }^{186}$ "[I]f a Kansas court holds that there is no common interest" privilege and "orders the disclosure" of communications shared among parties outside of Kansas, "Kansas law will [essentially] negate the privilege law of [the] other jurisdictions." 187 Thus, opposing counsel will be able to obtain information that otherwise would have been privileged in that jurisdiction, but negated by Kansas. ${ }^{188}$

A Kansas rejection of the common interest doctrine would also have consequences on the doctrine nationally. It would be impossible for coparties to confidently share privileged information in states where the common interest doctrine is alive and well, for fear of a potential similar suit

\footnotetext{
182. See discussion infra notes $212-234$ and accompanying text.

183. See discussion infra notes 212-234 and accompanying text.

184. See discussion infra notes 212-234 and accompanying text.

185. Amicus Brief for Product Liability Advisory Council, supra note 170, at*1.

186. Sprague v. Thorn Ams., Inc., 129 F.3d 1355, 1369 (10th Cir. 1997) (discussing differences between federal and state privilege law).

187. See Amicus Brief for Product Liability Advisory Council, supra note 170, at *8; RESTATEMENT (SECOND) OF CONFLICT OF LAWS $§ 139$ (AM. LAW INST. 1988).

188. Amicus Brief for Product Liability Advisory Council, supra note 170, at *8.
} 
in Kansas. ${ }^{189}$ Additionally, if Kansas were a "lone ranger" in rejecting the common interest doctrine, parties would have an incentive to file in Kansas in order to gain access to communications that would be otherwise privileged under other states' law. ${ }^{190}$ This could lead to Kansas courts being swamped with claims in an effort to avoid an evidentiary privilege that the majority of other jurisdictions recognize. ${ }^{191}$

\section{The Common Interest Doctrine is Necessary to Best Serve the Purpose of Attorney-Client Privilege}

Kansas's recognition of the common interest doctrine would serve the purpose of the attorney-client privilege by encouraging the "free flow of information... [and] enhancing the effectiveness of counsel." 192 If the purpose of attorney-client privilege is to be served, attorneys and their clients must be able to predict with some certainty what communications or discussions will be privileged. ${ }^{193}$ Kansas's failure to recognize the doctrine, or even engage in a guiding discussion about it, makes it difficult for Kansas attorneys to predict what communications will remain privileged if shared with a commonly interested third party. Kansas attorneys can hardly serve their clients in the most effective manner when the courts have left them with such uncertainty about an integral privilege.

Critics of the common interest doctrine argue that "it broadens the attorney-client privilege, which is generally construed narrowly" in favor of "the over-arching search for [the] truth." "194 However, the common interest doctrine attaches only to communications that would already be protected by attorney-client privilege. ${ }^{195}$ It does not broaden attorney-client privilege because careful parties arguably would not share those communications in the first place. An appropriate application of the doctrine allows attorneyclient privilege to function in a way that best serves its goals - "to encourage the free flow of information and to enhance the quality of legal advice"-

\footnotetext{
189. Id. at *8-9.

190. See id. at $* 9$ (assuming the parties meet all other jurisdictional criteria).

191. Id.

192. Schaffzin, supra note 18, at 57; see, e.g., In re Grand Jury Subpoenas, 89-3 \& 89-4, John Doe 89-129, 902 F.2d 244, 249 (4th Cir. 1990) (quoting United States v. Schwimmer, 892 F.2d 237, 243-44 (2d Cir. 1989)); Visual Scene, Inc. v. Pilkington Bros., 508 So. 2d 437, 440 (Fla. Dist. Ct. App. 1987).

193. Upjohn Co. v. United States, 449 U.S. 383, 393 (1981).

194. Schaffzin, supra note 18, at 68; see also Ambac Assurance Corp. v. Countrywide Home Loans, Inc., 57 N.E.3d 30, 34-40 (N.Y. 2016) (explaining the development of the joint defense and common interest doctrines and weighing the benefits of privilege with the potential loss of evidence).

195. Schaffzin, supra note 18 , at 55-56.
} 
especially when interests are aligned. ${ }^{196}$ When the common interest doctrine is clearly defined, it allows both attorneys and courts to predict and respect attorney-client privilege. ${ }^{197}$

3. Recognizing the Common Interest Doctrine Promotes Efficiency and Eliminates Unnecessary Costs

The common interest doctrine encourages parties with a common legal interest to seek assistance, obtain sound legal advice, and plan their actions in order to comply with the law. ${ }^{198}$ Thus, by avoiding litigation in the first place, both the judicial system and the parties avoid unnecessary expenditures of time and money. Additionally, collaboration between coparties reduces time and expenses and facilitates better preparation, thus advancing the parties' representation and streamlining the judicial process. ${ }^{199}$

Rejecting the common interest doctrine leads to unnecessary costs because it requires parties to unnecessarily duplicate work. Especially in litigation situations, if parties on the same side cannot share information without waiving attorney-client privilege, they are forced to hire multiple experts, write duplicative pleadings, and engage in large discovery disputes. $^{200}$ In Smith v. Philip Morris Cos., the court was forced to appoint a special master in order to deal with the volume of discovery disputes regarding whether the joint defense doctrine and the common interest doctrine were recognized in Kansas courts. ${ }^{201}$ Smith is unlikely to be the last case with this issue, and by recognizing the common interest doctrine, Kansas courts can avoid the expenses associated with such appointments in litigation. Additionally, as discussed above, a rejection of the common interest doctrine would burden Kansas with claims solely because their privilege law departs from that of other jurisdictions. ${ }^{202}$

\footnotetext{
196. Id. at 51 .

197. Id. at 67-68.

198. United States v. BDO Seidman, LLP, 492 F.3d 806, 816 (7th Cir. 2007) (quoting In re Regents of Univ. of Cal., 101 F.3d 1386, 1390-91 (Fed. Cir. 1996)).

199. See In re Qwest Commuc'ns Int'l, 450 F.3d 1179, 1195 (10th Cir. 2006) (noting that the joint defense doctrine or common interest doctrine "advances the representation of the party and the attorney's preparation of the case"); In re LTV Sec. Litig., 89 F.R.D. 595, 604 (N.D. Tex. 1981) (noting that recognizing the joint defense privilege "makes savings in expense and effort likely").

200. See Amicus Brief for Product Liability Advisory Council, supra note 170, at *8-12.

201. See Smith v. Philip Morris Cos., 335 P.3d 644, 661-62 (Kan. Ct. App. 2014).

202. See supra notes $189-91$ and accompanying text.
} 


\section{K.S.A section 60-426(b) Implicitly Recognizes the Common Interest Doctrine}

The common interest doctrine is implicit in Kansas's attorney-client privilege statute; thus, an explicit recognition of the doctrine aligns with Kansas's current law. However, before recognizing a formal version of the common interest doctrine, Kansas should confirm the joint defense doctrine's validity. While State v. Maxwell originally recognized the joint defense doctrine in Kansas in the criminal context, its validity has since become unclear. ${ }^{203}$ However, as it stands, the language of Kansas's attorney-client privilege statute may already recognize the joint defense and joint client doctrines.

Under K.S.A. section 60-426(a), communications between an attorney and her client are privileged when made in the "course of that relationship and in professional confidence." 204 K.S.A. section 60-426(b) lists the exceptions to attorney-client privilege. ${ }^{205}$ Subsection 60-426(b)(5) provides: "Such privileges shall not extend to a communication:... relevant to a matter of common interest between two or more clients if made by any of them to an attorney whom they have retained in common when offered in an action between any of such clients." 206 This exception applies when an attorney has multiple clients in the same case, and those clients are later engaged adversely to one another; communications between the client and that common attorney are not privileged in the later adverse action. ${ }^{207}$

It seems clear that this language acts as a codification of Maxwell, and the lack of civil versus criminal and plaintiff versus defendant language arguably extends Maxwell to civil co-parties as well. The language supports the proposition that the Kansas legislature intended confidential communications among jointly aligned co-parties and their common counsel to retain attorney-client privilege. There would be no exception to the privilege if those communications were not privileged to begin with. ${ }^{208}$ The statute makes no mention of whether the parties, before the action between them, were aligned as plaintiffs or defendants. ${ }^{209}$ Thus, it seems clear that this is a recognition of at least the joint defense/joint-client doctrine. However, Judge Smith's ruling in Philip Morris Cos. denied the existence of

\footnotetext{
203. See discussion supra Section II.F.

204. Kan. Stat. AnN. § 60-426(a) (Supp. 2016).

205. § 60-426(b)(1)-(5).

206. $\S 60-426(\mathrm{~b})(5)$ (emphasis added).

207. See id.

208. See Amicus Brief of the KADC, supra note 168 , at *11-15.

209. See § 60-426.
} 
such a privilege. ${ }^{210}$ While a recognition of the joint defense/joint client doctrines and the common interest doctrine would best serve the attorneys and clients of Kansas, a clarification either way is necessary.

It should be noted that Kansas courts do not need statutory authority under K.S.A. section 60-426 to recognize the common interest doctrine. While the common interest doctrine can be codified, it is not a new privilege, but an extension of attorney-client privilege as a common law privilege. ${ }^{211}$ Therefore, the court is free to recognize the common interest doctrine through common law as well. Nevertheless, this Comment argues that the language of section 60-426 indeed already supports such a ruling. Additionally, even if the statute implicitly recognizes the joint defense and/or common interest doctrine, it is not clear enough to be controlling. Thus, Kansas courts, or the legislature, need to provide attorneys with more certainty, whether through common law or statute.

\section{Highly Persuasive Jurisdictions Recognize the Common Interest Doctrine}

The national trend supports Kansas's recognition of the common interest doctrine because the majority of states and federal circuits already recognize the common interest doctrine. This trend is persuasive in itself. Moreover, two jurisdictions especially persuasive to Kansas-Kansas federal courts and Delaware-recognize and apply the common interest doctrine consistently. ${ }^{212}$

\section{a. Kansas Federal Courts}

The United States District Court for the District of Kansas and the Tenth Circuit Court of Appeals have explicitly recognized both the joint defense and common interest doctrines. ${ }^{213}$ While these decisions are not binding on Kansas state courts, Kansas state courts should follow in the steps of their federal counterparts in recognizing the common interest doctrine.

210. See Amended Brief \& Cross-Appeal, supra note 2, at *14-24; Drumwright \& Jones, supra note 168 , at 3 .

211. See discussion supra Section II.A.

212. See discussion infra Section III.A.5.

213. See, e.g., In re Qwest Commc'ns Int'l Inc., 450 F.3d 1179, 1195 (10th Cir. 2006); Frontier Ref. Inc. v. Gorman-Rupp Co., 136 F.3d 695, 705 (10th Cir. 1998); United States v. Dillard, No. 111098-JTM-KGG, 2013 WL 74316, at *3-4 (D. Kan. Jan. 7, 2013); High Point SARL v. Sprint Nextel Corp., No. 09-2269-CM-DJW, 2012 WL 234024, at *5-9 (D. Kan. Jan. 25, 2012); Sawyer v. Sw. Airlines, Nos. Civ.A.01-2385-KHV, Civ.A.01-2386-KHV, 2002 WL 31928442, at *2-4 (D. Kan. Dec. 23, 2002). 
Because Kansas federal courts applying Kansas law are especially persuasive, the District of Kansas's common interest doctrine recognition should influence Kansas state courts. ${ }^{214}$ Federal courts look to state law in deciding privilege questions when presented with both federal and state claims. $^{215}$ The District of Kansas (applying Kansas law) applied the common interest doctrine in Sawyer v. Southwest Airlines, noting that the lack of Kansas case law or statute recognizing the common interest doctrine was not fatal. ${ }^{216}$ In support of the ruling, it quoted the Kansas Supreme Court: "[T]he attorney-client privilege is important to the administration of justice and should not be set aside lightly." ${ }^{217}$ Because the District of Kansas applied the common interest doctrine while looking to Kansas privilege law for guidance, a Kansas state court recognition logically follows.

The Court of Appeals for the Tenth Circuit also recognizes the doctrine: "[W]hen the disclosure is to a party with a common interest, the... 'common interest' doctrine provides an exception to waiver because disclosure advances the representation of the party and the attorney's preparation of the case." ${ }^{218}$ Additionally, the Tenth Circuit, interpreting Kansas privilege law, cited the Kansas attorney-client privilege statute's broad language to conclude that Kansas prefers a broad approach to privilege. $^{219}$ While Kansas courts are not required to follow Tenth Circuit decisions, they are considered persuasive authority. ${ }^{220}$

When Kansas statutes are modeled after federal statutes, federal decisions interpreting those statutes are persuasive for interpreting and applying the Kansas statute. ${ }^{221}$ While the Kansas and federal attorney-client

214. See, e.g., State v. Dillingham, No. 99,189, 2008 WL 5428180, at *3 (Kan. Ct. App. Dec. 24, 2008) (discussing the federal impact on state court's creation and modification of the prison mailbox rule, noting that "this court has consistently been guided by federal precedent in addressing the rule and has treated federal law as very persuasive authority").

215. See FED. R. EvID. 501; Sprague v. Thorn Ams., Inc., 129 F.3d 1355, 1368-69 (10th Cir. 1997) (first citing Motley v. Marathon Oil Co., 71 F.3d 1547, 1551 (10th Cir. 1995); then citing FED. R. EvID. 501, and White v. Am. Airlines, Inc., 915 F.2d 1414, 1424 (10th Cir. 1990)).

216. Sawyer, 2002 WL 31928442, at*3.

217. Id. (quoting Wallace, Saunders, Austin, Brown \& Enochs, Chartered v. Louisburg Grain Co., 824 P.2d 933, 940 (Kan. 1992)).

218. In re Qwest Commc'ns Int'1 Inc., 450 F.3d 1179, 1195 (10th Cir. 2006).

219. Sprague, 129 F.3d at 1371 (citing KAN. StAT. AnN. § 60-426 (1995)).

220. Westar Energy, Inc. v. Wittig, 235 P.3d 515, 525 (Kan. Ct. App. 2010) (citing State v. Thompson, 166 P.3d 1015, 1039 (Kan. 2007)) (affirming trial court's decision which relied on Delaware and Tenth Circuit law, among other states, to rule on an issue of first impression and finding that the "Tenth Circuit Court of Appeals decisions are persuasive authority .....").

221. Ternes v. Galichia, 305 P.3d 617, 620-21 (Kan. 2013) (applying the Federal Rules of Civil Procedure to interpret the Kansas intervention statute). 
privilege statues are not identical, they function as such. ${ }^{222}$ As the Sawyer court stated, whether the court applied Kansas or federal law makes no difference, because the elements of attorney-client privilege under each are essentially identical. ${ }^{223}$ Thus, Kansas should follow federal precedents applying Kansas attorney-client privilege and, subsequently, the common interest doctrine.

Kansas would not be the first jurisdiction to recognize the common interest doctrine based off its respective federal court. The Court of Appeals of Michigan took a similar approach in recognizing the common interest doctrine in D'Alessandro Contracting Group, LLC v. Wright. ${ }^{224}$ The court reasoned that the "[f]ederal courts' application of the common-interest doctrine [was] instructive." 225 "[B] ecause both the state and federal rules" were "virtually identical," Michigan relied on federal cases for guidance in the state court's recognition of the common interest doctrine. ${ }^{226}$ Kansas should follow Michigan's example and use the federal courts' recognition of the common interest doctrine as guidance for Kansas state courts.

\section{b. Delaware}

Delaware recognizes a broad version of the common interest doctrine and Kansas's failure to recognize the doctrine disadvantages Kansas corporations relying on Delaware law. Kansas has a long history of reliance on Delaware corporate law for guidance in applying Kansas corporation law, as most of it is "nearly identical" to Delaware's. ${ }^{227}$ While attorney-client privilege and corporation law are clearly very different aspects of the law, they become remarkably intermingled in the application of the common interest doctrine. ${ }^{228}$ As such, Kansas should look to Delaware's formation of the common interest doctrine.

Delaware's common interest doctrine is codified in the Delaware Uniform Rules of Evidence 502(b)(3):

222. See Kan. Stat. AnN. § 60-426 (Supp. 2016); Fed. R. Evid. 502. But see Sawyer, 2002 WL 31928442 , at $* 2$.

223. Sawyer, 2002 WL 31928442 , at $* 2$.

224. 862 N.W.2d 466, 473-74 (Mich. Ct. App. 2014).

225. Id. at 474 .

226. Id. at 474-77 (quoting Leibel v. Gen. Motors Corp., 646 N.W.2d 179, 188 (Mich. Ct. App. 2002) (using the "virtually identical" reasoning in interpreting the state's work product doctrine)).

227. Hesston Corp. v. Kays (In re Hesston Corp.), 870 P.2d 17, 42 (Kan. 1994); see also Kan. Heart Hosp., L.L.C. v. Idbeis, 184 P.3d 866, 878-79 (Kan. 2008).

228. See Upjohn Co. v. United States, 449 U.S. 383, 389-96 (1981); King, supra note 15, at 1421. 
A client has a privilege to refuse to disclose and to prevent any other person from disclosing confidential communications made for the purpose of facilitating the rendition of professional legal services to the client ... (3) by the client or the client's representative or the client's lawyer or a representative of the lawyer to a lawyer or a representative of a lawyer representing another in a matter of common interest ....

The comments to Rule 502(b)(3) confirm that the doctrine applies absent pending litigation. ${ }^{22}$ By accepting Delaware's corporation law, but ignoring its interpretation of the common interest doctrine, Kansas corporations and their attorneys are forced to mix and match law. The possibility of relying on the wrong precedent creates several issues including potential malpractice or the inadvertent waiver of attorney-client privilege.

Delaware has a long reputation of being one of the best states to incorporate in. ${ }^{230}$ Kansas, among other states, has modeled its corporate law off Delaware's to remain attractive to businesses. ${ }^{231}$ Delaware arguably chose to not require pending or anticipated litigation to maintain its corporate friendly climate.

Kansas corporations and attorneys are at a disadvantage because of this conflict between Kansas and Delaware law. The Kansas Secretary of State reported a record number of businesses formed in both 2014 and 2015. ${ }^{232}$ The total number of Kansas business entities in 2015 was $179,665 .^{233}$ If Kansas wants to continue this increase in business entities, it should look to more than just Delaware's corporation law. If Kansas recognizes the common interest doctrine, it is essential that it does so in a way that allows the privilege to function in certain forms of business transactions. This would provide Kansas attorneys with a more predictable privilege and would

229. DEL. R. EVID. 502(b)(3) cmt. ("D.R.E. 502(b) tracks U.R.E. 502(b) except that the word 'therein' and the words 'party in a pending action and concerning' were deleted and the word 'in' was inserted in lieu thereof in D.R.E. 502(b)(3). The purpose of this change was . . . to make it clear that D.R.E. 502(b)(3) applies even if no litigation is actually pending.").

230. See Randy J. Holland, Del. Bus. Courts: Litig. Leadership, Presentation at Corporation Service Company Continuing Legal Education: Delaware's Far-Reaching Influence on Corporate Law in the United States and Abroad 1-3 (Jan. 11, 2013), https://www.cscglobal.com/cscglobal/pdfs/Outline_20130111.pdf (outline of presentation); see also House Bill 2261 - Enacting the Revised Uniform Limited Liability Company Act (RULLCA): H.B. 2261 Before the H. Judiciary Comm., 2012 Leg. Sess. 2 (Kan. Feb. 2, 2012) (statement of William Quick, on behalf of Kan. Bar Ass'n, in opposition of H.B. 2261) [hereinafter Letter from William Quick],

http://kslegislature.net/li_2012/b2011_12/committees/misc/ctte_h_jud_1_20120202_04_other.pdf.

231. See Holland, supra note 230, at 2 (citing Letter from William Quick, supra note 230); see also Letter from William Quick, supra note 230, at 1-2.

232. Press Release, Kris Kobach, Kan. Sec'y of State, Total New Business Formations in Kansas Sets Another Record, KAN. OfFICE SEC'Y OF STATE (Feb. 8, 2016), http://www.sos.ks.gov/other/news_releases/PR_2016/NR_2016_2_8.pdf.

233. Id. 
incentivize Kansas businesses to negotiate and deal with one another in a way that complies with the law and reduces secrecy. Additionally, it allows Kansas corporate attorneys to rely on the law that has guided them for decades-Delaware's.

\section{B. How Kansas Should Recognize the Common Interest Doctrine}

Courts have adopted the common interest doctrine in several ways: some have codified their own version of the doctrine; some have modeled their code from Proposed Rule of Evidence 503(b); while others have left the doctrine to common law. ${ }^{234}$ Ideally, Kansas should codify the common interest doctrine to ensure that the doctrine is well defined and has appropriate boundaries. Kansas should adopt a broad version of the common interest doctrine to best serve the underlying purposes of both the doctrine and attorney-client privilege.

To ensure that the common interest doctrine is not abused and best serves its purpose - to encourage the free flow of information-Kansas must define the boundaries of the doctrine. Ideally, the elements for Kansas's recognition include: (1) a communication that is otherwise protected by attorney-client privilege; (2) made between two parties sharing a common legal interest; (3) the communication was made in furtherance of the common interest; and (4) the parties did not otherwise waive the privilege.

Jurisdictions agree that the doctrine cannot attach if the underlying communication would not have been protected by attorney-client privilege or if the parties have otherwise waived the privilege. As an initial matter, Kansas courts should ensure that the underlying communication qualifies as attorney-client privileged as defined by K.S.A. section 60-426(a): "[C]ommunications found by the judge to have been between an attorney and such attorney's client in the course of that relationship and in professional confidence, are privileged, and a client has a privilege ....,235 Once the court determines that the underlying communication is attorneyclient privileged and the parties did not otherwise waive the privilege, it can turn to the applicability of the common interest doctrine. Thus, this Comment focuses on how Kansas should define more disputed elements: "between two parties sharing a common legal interest;" and "the communication was made in furtherance of the common interest."

234. See supra notes 112-39 and accompanying text.

235. KAN. StAT. ANN. § 60-426(a) (Supp. 2016). 


\section{Between Two Parties Sharing a Common Legal Interest}

First, Kansas should not define the doctrine based on the position of the parties (criminal co-defendants; civil co-defendants; civil co-plaintiffs, etc.). The national trend applies the common interest doctrine to parties sharing a sufficiently common interest, regardless of their position. ${ }^{236}$ Moreover, restricting the doctrine based on the position of the parties creates confusion between the common interest doctrine and other doctrines such as the joint defense or joint client doctrines. ${ }^{237}$ Thus, Kansas should apply the common interest doctrine to qualified parties, regardless of their position.

Second, Kansas should define a "common legal interest" with some flexibility - the interest should be substantially common, but not necessarily identical. Yet, Kansas should join the majority of other jurisdictions in requiring that the interest is legal, and not solely commercial. ${ }^{238}$ Parties clearly have a common legal interest when they are engaged as co-parties in litigation. ${ }^{239}$ However, outside of the litigation context, whether parties share a common legal interest can be highly fact dependent.

In situations where the commonality is at issue, Kansas courts should require that the parties' common interests outweigh any of the parties' adverse interests. Using a balancing test ensures that the courts can evaluate the common interest with some discretion and act as a "gate keeper" for parties attempting to use the doctrine to cheat the system. ${ }^{240}$ At the same time, parties seeking privilege under the doctrine for the furtherance of a truly common interest should have no trouble showing that to the court.

However, Kansas should consciously require that parties share a true "legal interest." For example, in the transactional context, Kansas should be wary of applying the doctrine to communications made outside of due diligence. Courts should consider whether the transaction will lead to a "transfer of liabilities from one party to the other" as a basis for whether the parties shared a common interest. ${ }^{241}$ This reasoning can apply to numerous situations including mergers, acquisitions, patent sales, and negotiations. Applying the doctrine outside these transactional situations raises the risk of parties using the doctrine for leverage or to persuade investors as opposed to

\footnotetext{
236. See supra notes 112-39 and accompanying text.

237. See discussion supra Section II.C.

238. See discussion supra Section II.D.1.

239. Niagara Mohawk Power Corp. v. Megan-Racine Assocs., Inc. (In re Megan-Racine Assocs., Inc.), 189 B.R. 562, 573 (Bankr. N.D.N.Y. 1995).

240. See Schaffzin, supra note 18, at 76-78; Duplan Corp. v. Deering Milliken, Inc., 397 F. Supp. 1146, 1172 (D.S.C. 1975).

241. King, supra note 15, at 1435-36.
} 
compliance with the law. Situations involving a transfer of liability are more likely to serve the interests of parties with actual common interests, instead of using common interest for secrecy. ${ }^{242}$

Third, and most importantly, Kansas should not require pending or anticipated litigation for the common interest doctrine to attach. Requiring pending or anticipated litigation departs from attorney-client privilege's common law roots. ${ }^{243}$ The underlying purpose of both attorney-client privilege and the common interest doctrine is "to encourage the free flow of information and to enhance the quality of legal advice."244 Attorney-client privilege does not require pending or anticipated litigation to attach, most notably because litigation is not always the motivating factor for a client's communication of private information. ${ }^{245}$

There are a number of important legal situations outside of litigation where parties have common legal interests. ${ }^{246}$ For example, the corporate attorney-client privilege encourages seeking legal advice in order to comply with the complex regulations many companies face. ${ }^{247}$ Given that corporations generally face more complex legal issues than individuals, they likely seek legal advice more often, and thus have a larger number of privileged communications. ${ }^{248}$ A number of other courts have joined this line of reasoning, as explained by the United States District Court for the District of Connecticut: "The timing and setting of the communications are important indicators of the measure of common interest; the shared interest necessary to justify extending the privilege to encompass intercorporate communications appears most clearly in cases of co-defendants and impending litigations but is not necessarily limited to those situations."249 The "real inquiry" underlying the common interest doctrine "is not whether litigation is pending or anticipated, but whether the interest" is common and legal. ${ }^{250}$ Moreover, the idea of "anticipated litigation" is ambiguous and

242. See id.

243. See Ambac Assurance Corp. v. Countrywide Home Loans, Inc., 57 N.E.3d 30, 41-43 (N.Y. 2016) (Rivera, J., dissenting).

244. Schaffzin, supra note 18, at 51; see, e.g., In re Grand Jury Subpoenas, 89-3 \& 89-4, John Doe 89-129, 902 F.2d 244, 249 (4th Cir. 1990) (quoting United States v. Schwimmer, 892 F.2d 237, 243-44 (2d Cir. 1989)); Visual Scene, Inc. v. Pilkington Bros., 508 So. 2d 437, $440-41$ (Fla. Dist. Ct. App. 1987).

245. Ambac, 57 N.E.3d at 41 (Rivera, J., dissenting).

246. Sunshine, supra note 14, at 843-44.

247. See Upjohn Co. v. United States, 449 U.S. 383, 392-95 (1981).

248. King, supra note 15, at $1421 \&$ nn.55-56.

249. SCM Corp. v. Xerox Corp., 70 F.R.D. 508, 513 (D. Conn. 1976).

250. Schaffzin, supra note 18 , at 75 . 
vague, requiring additional judicial interpretation. ${ }^{251}$ Arguably, parties engaged in high risk industries could be anticipating litigation at any time.

There are valid arguments against protecting communications outside the presence of pending or anticipated litigation. The "litigation required" approach ensures a narrow application of the doctrine and creates a predictable categorical rule, limiting courts' discretion. ${ }^{252}$ Requiring anticipated or pending litigation eliminates the doctrine's application in settings where parties arguably never have a truly identical legal interestwhere parties are adverse or sitting on opposite sides of the negotiating table. $^{253}$ This type of a categorical rule would simplify application of the doctrine and thus could be more cost and time efficient for the courts. ${ }^{254}$ However, while these arguments are valid, they choose predictability and ease of application over serving the purposes of attorney-client privilege and the common interest doctrine. Moreover, a categorical rule goes against the Supreme Court's articulation of corporate attorney-client privilege, as articulated in Upjohn, and would impose an evidentiary rule on private transactions. ${ }^{255}$

Rejecting a litigation requirement would provide Kansas attorneys more certainty about what communications are privileged and encourage the free flow of information. Additionally, by not imposing a litigation requirement, Kansas courts would align themselves with similarly aligned, persuasive jurisdictions - the United States District Court for the District of Kansas, the U.S. Court of Appeals for the Tenth Circuit, and Delaware. ${ }^{256}$

\section{The Communication Was Made in Furtherance of the Common Interest}

Kansas should require that the communication is made in furtherance of the common interest to ensure that parties are only sharing privileged communications that actually relate to their common interest. For example, there are situations where two parties clearly have a common legal interest, but they may also have a number of common non-legal interests. The existence of a common interest is not sufficient to warrant privilege, rather,

251. See Ambac Assurance Corp. v. Countrywide Home Loans, Inc., 57 N.E.3d 30, 45 (N.Y. 2016) (Rivera, J., dissenting).

252. King, supra note 15 , at 1432-33.

253. See Ambac, 57 N.E.3d at 37-40 (majority opinion); King, supra note 15, at 1432-33.

254. See King, supra note 15, at 1432-37.

255. See Upjohn Co. v. United States, 449 U.S. 383, 392-93 (1981); King, supra note 15, at 1421, 1427-29 (discussing Hewlett-Packard Co. v. Bausch \& Lomb Inc., 115 F.R.D. 308, 310-11 (N.D. Cal. 1987)).

256. See discussion supra notes $213-33$ and accompanying text. 
the parties must demonstrate a collective cooperation in developing a common legal strategy. ${ }^{257}$ If Kansas allowed parties with a common interest to claim privilege for all communications between them, the doctrine would become too broad and susceptible to abuse.

Additionally, Kansas should require the communications to be made through each party's respective counsel, as opposed to between the parties themselves. Again, if parties with a common interest could claim privilege on all communications between them, the doctrine becomes boundless. Requiring the communication be made between the attorneys ensures that the interest is legal, and creates a more definite boundary for where the privilege applies. This requirement is also beneficial to discovery, as communications eligible for the common interest privilege would have already been filtered through counsel. Kansas should make clear that any communications between the parties themselves, regardless of how common their interest, would constitute a waiver of privilege.

\section{What Kansas Attorneys Can Do in the Meantime}

Kansas should recognize the common interest doctrine either judicially or codified through the legislature. The doctrine is long overdue for discussion in Kansas, but it would be unwise for parties to rely on it in the meantime. While State v. Maxwell has not been overruled, is technically still good law, and arguably can be relied on, the more recent cases questioning the validity of Maxwell should serve as a warning to parties seeking to use the joint defense privilege, and especially the common interest doctrine. ${ }^{258}$ Kansas attorneys seeking to use the common interest doctrine should be wary to do so in any Kansas state court, as the court's response is unpredictable and potentially unfavorable.

However, as many attorneys practice in multiple jurisdictions, it is helpful to know what parties can do to sway the presumption towards privilege. Courts have identified several things parties can do to support a finding of privilege in a common interest situation including the parties' efforts to maintain confidentiality and the existence of a written agreement. Parties' handling of privileged communications has also swayed courts towards a finding of privilege. ${ }^{259}$ Thus, parties should take sufficient effort to maintain the communications' confidentiality, such as limiting the number of copies, limiting the shared communication to what is absolutely

257. See In re Leslie Controls, Inc., 437 B.R. 493, 496-97 (Bankr. D. Del. 2010).

258. See discussion supra Section II.F.

259. See, e.g., Hewlett-Packard, 115 F.R.D. at 309. 
necessary, restricting who can access the copies, and requesting the return of the copies. ${ }^{260}$

A written agreement may not be required under the common interest doctrine, but courts have found them to be persuasive as evidence of a common interest. Non-disclosure agreements, joint defense agreements, common interest agreements, or confidentiality agreements can be especially persuasive. ${ }^{261}$ In fact, depending on the court, parties risk an adverse finding of common interest prior to the execution of a written agreement. ${ }^{262}$ The written agreement should tie the agreement to pending or anticipated litigation and include a choice of law provision. ${ }^{263}$ If possible, parties using a written common interest agreement should choose a jurisdiction that recognizes a broad scope of common interest protection-such as Massachusetts or Delaware - as the governing law of the agreement. Additionally, each communication should be marked "Privileged and Confidential/Attorney Work-Product" and ideally contain some legal advice.

However, the existence of a written agreement will not create a privilege where one does not rightfully exist. ${ }^{264}$ Therefore, attorneys should educate themselves on whether the jurisdiction recognizes the common interest doctrine, and to what extent. The existence of a written agreement will not terminate the requirements of both attorney-client privilege and the common interest doctrine - the parties must still establish that the communications are privileged under both. ${ }^{265}$

260. See, e.g., id. (holding that privilege was not waived when "defendant took substantial steps to assure that GEC maintained the confidentiality of the letter[:] [o]nly two copies were transmitted to GEC; GEC was instructed that no further copies were to be made; both copies were returned to defendant's counsel; and the letter was not disclosed to others").

261. See, e.g., MobileMedia Ideas LLC v. Apple Inc., 890 F. Supp. 2d 508, 518 (D. Del. 2012); HSH Nordbank AG N.Y. Branch v. Swerdlow, 259 F.R.D. 64, 72-73, 72 n.12 (S.D.N.Y. 2009) ("[W]hile Nordbank and the non-party lenders wisely chose to reduce their common agreement to writing, their decision to do so does not mean that there was no prior agreement. To the contrary, Nordbank has made a persuasive showing that the parties shared a common interest ...."); Tenneco Packaging Specialty \& Consumer Prods. v. S.C. Johnson \& Son, Inc., No. 98 C 2679, 1999 WL 754748 , at $* 2$ (N.D. Ill. Sept. 14, 1999).

262. E.g., In re Grand Jury Subpoena: Under Seal, 415 F.3d 333, 341 (4th Cir. 2005) (finding that parties had no joint defense/common interest before the date of execution on a common interest agreement).

263. LaBrie, supra note 119 .

264. U.S. Fire Ins. Co. v. Bunge N. Am., Inc., No. 05-2192 JWL-DJW, 2006 WL 3715927, at *1-3 (D. Kan. Dec. 12, 2006) (declining to apply common interest or joint defense privilege where parties failed to establish an underlying attorney-client privilege and failed to establish the elements of the common interest doctrine, even though the parties had entered into a written common interest agreement).

265. Id. 


\section{CONCLUSION}

The common interest doctrine is an important aspect of attorney-client privilege law and Kansas should recognize it as such. Kansas's failure to recognize the common interest doctrine is problematic for attorneys, their clients, and the judicial system. It is contrary to the national trend and creates uncertainty surrounding attorney-client privilege. As such, Kansas attorneys and their clients cannot predict how the law will apply, and thus cannot conduct themselves accordingly. As a late adopter, Kansas has a unique opportunity to evaluate other jurisdictions' common interest doctrine application, and choose a form of the doctrine that best fits Kansas's goals.

The ideal solution is for Kansas to recognize the common interest doctrine either through common law, or by incorporating it into its attorneyclient privilege statute, K.S.A. $\S 60-426$. Regardless of the means, Kansas's common interest doctrine should be clearly defined and fairly broad, consisting of the following elements: (1) a communication that is otherwise protected by attorney-client privilege; (2) made between two parties sharing a common legal interest; (3) in furtherance of the common interest; and (4) the parties did not otherwise waive the privilege. This form would allow parties to more certainly predict whether information will be disclosed, furthers the rationale behind attorney-client privilege, and allows Kansas courts to ensure that the doctrine is not abused. While this Comment proposes elements of an ideal common interest doctrine, recognizing any form would be an improvement from prolonged uncertainty that Kansas currently faces. 